This item was submitted to Loughborough's Research Repository by the author.

Items in Figshare are protected by copyright, with all rights reserved, unless otherwise indicated.

\title{
Intensified degradation and mineralization of antibiotic metronidazole in photo-assisted microbial fuel cells with Mo-W catalytic cathodes under anaerobic or aerobic conditions in the presence of $\mathrm{Fe}(\mathrm{III})$
}

\section{PLEASE CITE THE PUBLISHED VERSION}

https://doi.org/10.1016/j.cej.2018.07.168

\section{PUBLISHER}

(C) Elsevier

\section{VERSION}

AM (Accepted Manuscript)

\section{PUBLISHER STATEMENT}

This work is made available according to the conditions of the Creative Commons Attribution-NonCommercialNoDerivatives 4.0 International (CC BY-NC-ND 4.0) licence. Full details of this licence are available at: https://creativecommons.org/licenses/by-nc-nd/4.0/

\section{LICENCE}

CC BY-NC-ND 4.0

\section{REPOSITORY RECORD}

Wang, Qiang, Zhenghong Cai, Liping Huang, Yuzhen Pan, Xie Quan, and Gianluca Li-Puma. 2019. "Intensified Degradation and Mineralization of Antibiotic Metronidazole in Photo-assisted Microbial Fuel Cells with Mo-w Catalytic Cathodes Under Anaerobic or Aerobic Conditions in the Presence of Fe(iii)". figshare. https://hdl.handle.net/2134/37019. 
SI: New AOPs developments

July 23, 2018

Intensified degradation and mineralization of antibiotic metronidazole in photo-assisted microbial fuel cells with Mo-W catalytic cathodes under anaerobic or aerobic conditions in the presence of $\mathrm{Fe}($ III)

Qiang Wang ${ }^{1}$, Zhenghong Cai ${ }^{1}$, Liping Huang ${ }^{1, *}$, Yuzhen Pan $^{2}$, Xie Quan ${ }^{1}$, Gianluca Li Puma ${ }^{3, *}$

1. Key Laboratory of Industrial Ecology and Environmental Engineering, Ministry of Education (MOE), School of Environmental Science and Technology, Dalian University of Technology, Dalian 116024, China

2. College of Chemistry, Dalian University of Technology, Dalian 116024, China

3. Environmental Nanocatalysis \& Photoreaction Engineering, Department of Chemical Engineering, Loughborough University, Loughborough LE11 3TU, United Kingdom

Corresponding authors:

(L. Huang) lipinghuang@dlut.edu.cn

(G. Li Puma) g.lipuma@lboro.ac.uk

Q. Wang and Z. Cai equally contribute to this article.

The authors declare no competing financial interest. 


\section{Abstract}

A novel strategy to intensify the degradation and mineralization of the antibiotic drug metronidazole (MNZ) in water with simultaneous production of renewable electrical energy was achieved in photo-assisted microbial fuel cells (MFCs). In this system Mo and W catalytic species immobilized onto a graphite felt cathode intensified the cathodic reduction of MNZ under anaerobic conditions and the oxidation of MNZ under aerobic conditions. The aerobic oxidation process was further accelerated in the presence of $\mathrm{Fe}(\mathrm{III})$, realizing a combined photo-assisted MFCs and Fenton-MFCs process. The highest rates of MNZ degradation $(94.5 \pm 1.4 \% ; 75.6 \pm 1.1 \mathrm{mg} / \mathrm{L} / \mathrm{h})$ and mineralization $(89.5 \pm 1.1 \% ; 71.6 \pm 0.9 \mathrm{mg} / \mathrm{L} / \mathrm{h})$, and power production $\left(251 \mathrm{~mW} / \mathrm{m}^{2} ; 0.015 \mathrm{kWh} / \mathrm{m}^{3}\right.$; $0.22 \mathrm{kWh} / \mathrm{kg} \mathrm{COD}$ ) were achieved at a Mo/W loading of $0.18 \mathrm{mg} / \mathrm{cm}^{2}$ with a $\mathrm{Mo} / \mathrm{W}$ ratio of 0.17 : 1.0 , in the presence of $10 \mathrm{mg} / \mathrm{L}$ of $\mathrm{Fe}(\mathrm{III})$ and at an incident photon flux of $23.3 \mathrm{~mW} / \mathrm{cm}^{2}$. Photo-generated holes were directly involved into the oxidation of MNZ under anaerobic conditions. Conversely, under aerobic conditions, the photo-generated electrons favored the production of $\mathrm{O}_{2}{ }^{-}$ over $\bullet \mathrm{OH}$, while in the presence of $\mathrm{Fe}(\mathrm{III}), \bullet \mathrm{OH}$ was predominant over $\mathrm{O}_{2} \bullet^{-}$, explaining the intensification of the MNZ mineralization observed. This study demonstrates an alternative and environmentally benign approach for the intensification of the removal of the antibiotic MNZ in water and possibly other contaminants of emerging concern by combining photo-assisted MFCs and Fenton-MFCs in a single process with simultaneous production of renewable electrical energy.

Keywords: photo-assisted microbial fuel cell; Fenton-microbial fuel cell; W and Mo catalysts; metronidazole; degradation; mineralization 


\section{Introduction}

The widespread use of the antibacterial and antiprotozoal metronidazole (2-methyl-5-nitroimidazole-1-ethanol, MNZ) in human and veterinary medicine has raised concerns over the impact of this drug on the aquatic environment. In fact, residual concentrations of MNZ have been frequently detected in hospital effluents, wastewater, surface water and groundwater [1-3]. Furthermore, the occurrence of MNZ in the environment leads to the development of MNZ-resistant bacteria, causing the loss of the therapeutic properties of the drug. The elimination of the antibiotic MNZ from water system is therefore an important issue considering its toxicity, potential mutagenicity and carcinogenicity [1-3].

A range of treatment methods have been proposed for the treatment of MNZ wastewater including adsorption, biological method, electrochemical reduction, and reduction on nanoscale zero-valent iron [2,4-6]. However, all the above methods have drawbacks. The adsorption process only transfers the contaminants from the water to a solid phase without further degradation, the biological method usually requires long treatment periods, zero-valent iron reduction leads to the formation of sludge and refractory intermediates, while electrochemical processes usually require large energy consumption. In consequence, the further development of effective, environmental friendly and cost-effective strategies for the treatment of MNZ wastewater are required.

Advanced oxidation processes have been proposed for the degradation of MNZ in water [3,7-18]. Different photocatalysts including $\mathrm{TiO}_{2}$ [3], $\mathrm{Ag} / \mathrm{ZnO}$ [7], 
$\mathrm{ZnSnO}_{3} / \mathrm{ZnO} /$ nano-ZnO [13-14], $\mathrm{ZnS}-\mathrm{NiS} /$ zeolite [15], $\mathrm{TiO}_{2} / \mathrm{ZnIn}_{2} \mathrm{~S}_{4}$ [16], and $\mathrm{Fe}^{0} /$ graphene- $\mathrm{TiO}_{2}[12]$ have been developed for the degradation and mineralization of MNZ via the oxidizer of superoxide radical $\left(\mathrm{O}_{2} \bullet^{-}\right)$or photo-generated holes. The photo-Fenton process in the presence of iron species and $\mathrm{H}_{2} \mathrm{O}_{2}$ also mineralizes MNZ through the $\cdot \mathrm{OH}$ radicals produced from the decomposition of $\mathrm{H}_{2} \mathrm{O}_{2}$ (Eqs. 1-2) and the photoreduction of iron species (Eqs. 3-4) [10]. The need for external dosing of $\mathrm{H}_{2} \mathrm{O}_{2}$, however increases the operating and maintenance costs of this technology [11]. Electron-Fenton and photo-electro-Fenton processes using graphite-based electrodes and $\mathrm{Pt}$ catalyst can in-situ produce $\mathrm{H}_{2} \mathrm{O}_{2}$ (Eq. 5) and degrade $\mathrm{MNZ}$ through $\bullet \mathrm{OH}$ (Eqs. 1-6) [9,17-18]. However, the large external energy consumption and the use of expensive catalysts limit their practical application. In general, further research on cost effective, efficient and sustainable processes is required to intensify the rate of degradation and mineralization of MNZ and of other antibiotics.

$$
\begin{aligned}
& \mathrm{H}_{2} \mathrm{O}_{2}+\mathrm{Fe}^{2+} \rightarrow \cdot \mathrm{OH}+\mathrm{Fe}^{3+}+\mathrm{OH}^{-} \\
& \mathrm{H}_{2} \mathrm{O}_{2}+h v \rightarrow 2 \cdot \mathrm{OH} \\
& \mathrm{Fe}^{3+}+\mathrm{H}_{2} \mathrm{O} \rightarrow \mathrm{Fe}(\mathrm{OH})^{2+}+\mathrm{H}^{+} \\
& \mathrm{Fe}(\mathrm{OH})^{2+}+h v \rightarrow \cdot \mathrm{OH}+\mathrm{Fe}^{2+} \\
& \mathrm{O}_{2}+2 \mathrm{H}^{+}+2 \mathrm{e}^{-} \rightarrow \mathrm{H}_{2} \mathrm{O}_{2} \\
& \mathrm{Fe}^{3+}+\mathrm{e}^{-} \rightarrow \mathrm{Fe}^{2+} \\
& \text { photocatalyst }+h v \rightarrow \mathrm{e}^{-}+\mathrm{h}^{+} \\
& \mathrm{e}^{-}+\mathrm{O}_{2} \rightarrow \mathrm{O}_{2}^{-} \\
& \mathrm{h}^{+}+\mathrm{H}_{2} \mathrm{O} \rightarrow \cdot \mathrm{OH}+\mathrm{H}^{+}
\end{aligned}
$$


Photo-assisted microbial fuel cells (MFCs) have recently emerged as a promising sustainable method for the simultaneous treatment of biodegradable organic electron donors on the anodes and recalcitrant organic electron acceptors on the cathodes in the presence of irradiation light, with the simultaneous generation of electricity [19-21]. Another process named as Fenton-MFCs also removes many recalcitrant organics through the in-situ generation of $\mathrm{H}_{2} \mathrm{O}_{2}$ in the presence of $\mathrm{Fe}(\mathrm{III})$, which produces highly reactive $\cdot \mathrm{OH}$ radicals [22-26]. In this paper we propose the integration of photo-assisted MFCs and Fenton-MFCs in a single process, as a new effective method for the intensification of the degradation and mineralization of recalcitrant organics. The simultaneous production of $\mathrm{OH}$ and $\mathrm{O}_{2}{ }^{-}$, and photo-generated holes in conventional photo-electro-Fenton processes (Eqs. 1-9) [27-30], will be exploited in this new integrated process to intensify the degradation and mineralization of MNZ in the cathodic chambers and thus the mineralization current efficiency and anodic coulombic efficiency $\left(C E_{\mathrm{an}}\right)$ of MFCs.

A range of cathodic catalytic material have been proposed for degradation of many organics species, such as graphite based rutile and nickel foam based $\mathrm{TiO}_{2}$ in photo-assisted MFCs [19-20,31], and carbon felt based $\mathrm{Fe} / \mathrm{Fe}_{2} \mathrm{O}_{3}$, carbon nanotubes based iron phthalocyanine, or graphite rod cathodes in Fenton-MFCs [22-26,32]. These catalytic materials absorb only a narrow range of the solar radiation spectrum and present conduction band potentials of less than $-0.54 \mathrm{~V}$ vs. standard hydrogen electrode (SHE) which are lower than the theoretical electrode potential for hydrogen evolution (-0.414 V vs. SHE). In consequence, these materials under light irradiation 
may withdraw electrons for hydrogen evolution which effectively decrease the effectiveness of the Fenton degradation process.

In sharp contrast, visible light active mixed transition metals of W-Mo oxides exhibit a much higher conduction band potential (0.40 V vs. SHE), which can suppress the parasite reaction of hydrogen evolution [33]. These species exhibit excellent properties in photo-assisted catalytic processes via the generation of $\mathrm{O}_{2}{ }^{-}$ and $\bullet \mathrm{OH}$ through the reaction of in-situ produced $\mathrm{H}_{2} \mathrm{O}_{2}$ in the presence of Fe species [34-36]. Considering the favorable properties of graphite felt for the in-situ production of $\mathrm{H}_{2} \mathrm{O}_{2}$ in MFCs [22-26], in this study we propose the use of W-Mo catalytic graphite felt cathodes to intensify the photo-assisted catalytic and electro-Fenton processes in MFCs.

Anaerobic and aerobic conditions may influence the activity of $\mathrm{W}$ and Mo catalytic species and thus the amount of $\mathrm{O}_{2}{ }^{\bullet^{-}}$and $\bullet \mathrm{OH}$ formed. In most cases, aerobic conditions favor the mineralization of organics through the attack of either $\mathrm{O}_{2} \bullet^{-}$ produced from photo-assisted catalytic process $[3,12-16]$ or $\bullet \mathrm{OH}$ generated from electrochemical direct oxidation, externally added $\mathrm{H}_{2} \mathrm{O}_{2}$ in Fenton system, or in-situ produced $\mathrm{H}_{2} \mathrm{O}_{2}$ in electro-Fenton/photo-electro-Fenton processes [1,9,17]. Conversely, anaerobic conditions are suitable for the electrochemical reduction of the nitro group in MNZ to the amino group [4]. Considering the effective role played by $\mathrm{W}$ and Mo catalytic species for oxygen reduction and hydrogen evolution [33-37], anaerobic conditions may accelerate the cathodic reduction of the nitro group in MNZ.

In this study, we propose a new and effective method to intensify the degradation 
and mineralization of MNZ through $\mathrm{W}$ and Mo catalytic cathodes incorporated in hybrid photo-assisted MFCs and Fenton-MFCs, under anaerobic or aerobic conditions. The impact of Mo/W loading and molar ratio were characterized and optimized to achieve effective degradation and mineralization of MNZ. The results and overall system performance were further explained by monitoring the $C E_{\mathrm{an}}$, the mineralization current efficiency, the circuital current and by linear sweep voltammetry (LSV), cyclic voltammetry (CV) and electrochemical impedance spectroscopy (EIS). The possible MNZ degradation and mineralization pathways were established based on probing the reactive species generated through radical scavenging experiments and on the analysis of the resulting reaction intermediates obtained during the degradation and mineralization of MNZ.

\section{Materials and methods}

\subsection{Reactor configuration}

Photo-assisted, two-chamber MFCs were assembled connecting two cubic polymethyl methacrylate blocks with an inner cylinder $3 \mathrm{~cm}$ in diameter. The two chambers were separated by a cation exchange membrane (CMI-7000 Membranes International, Glen Rock, NJ). Three-dimensional graphite felts $(2.0 \mathrm{~cm} \times 2.0 \mathrm{~cm} \times$ $0.5 \mathrm{~cm}$, Sanye Co., Beijing, China) served as anode and cathode electrodes [38-40]. The graphite felts at the anode were connected with a carbon rod and at the cathode with a titanium wire, and the external circuit was closed through a $200 \Omega$ resistor. The use of the $200 \Omega$ resistor resulted in optimal operation, in comparison to lower (10 $\Omega$ ) 
or higher (500 $\Omega$ ) resistors [41-42]. With such resistor consistently higher rates of MNZ degradation and $C E_{\text {an }}$ were achieved [Fig. S1A and D of Supporting Material (SM)] in concert with stable higher circuital currents (Fig. S1B) and lower anode potentials (Fig. S1C). All materials used were cleaned with the protocol described in Wang et al [43]. The effective operating volumes of both anode and cathode were 13 $\mathrm{mL}$ each. A saturated calomel reference electrode (SCE, $241 \mathrm{mV}$ vs. SHE) was placed in the cathode chamber to monitor the cathode potential, with all voltages reported here vs. SHE. The reactor anodes were wrapped in aluminum foil to exclude ambient light irradiation.

The MFC cathode was irradiated by a $100 \mathrm{~W}$ iodine tungsten lamp (wavelength range of $400-800 \mathrm{~nm}$ ), positioned parallel to the electrode, at a distance of $15 \mathrm{~cm}$, as shown elsewhere [19-20]. The incident photon irradiance was $23.3 \mathrm{~mW} / \mathrm{cm}^{2}$. The lamp was refrigerated by a cooling-fan and the MFCs were immersed in a thermostatic jacket, which maintained the temperature in the reaction chambers, isothermal at $22 \pm 3{ }^{\circ} \mathrm{C}$.

\subsection{Anode inoculation and acclimation}

The anodes were inoculated with the effluent from acetate-fed MFCs with an equivalent volume of nutrient solution, as previously reported [43-44]. The anodic medium contained (g/L): sodium acetate 1.0, $\mathrm{KH}_{2} \mathrm{PO}_{4} 4.4, \mathrm{~K}_{2} \mathrm{HPO}_{4} 3.4, \mathrm{NH}_{4} \mathrm{Cl}$ 1.3, $\mathrm{KCl}$ 0.78, $\mathrm{MgCl}_{2}$ 0.2, $\mathrm{CaCl}_{2}$ 0.0146, $\mathrm{NaCl} 0.5$, trace vitamins and minerals. The catholyte used during the anode acclimation period, was a $50 \mathrm{mM}$ phosphate buffer. 
Both anolyte and catholyte were replaced daily. An external resistance of $1000 \Omega$ was used during the exoelectrogen acclimation period [43-44]. The anodes were considered fully acclimated when the anode potential stabilized at around $-0.24 \mathrm{~V}$ for at least three successive batch cycles [43-44].

\subsection{Preparation of Mo/W coated graphite felt cathodes}

Mo and W species were deposited on the graphite felt cathode through a low-cost and facile liquid-phase electrodeposition method, which has its own intrinsic advantages over other deposition methods requiring high temperatures and costly equipment (e.g., vapor-phase deposition method) [45-46]. Briefly, the catholyte was replaced by a mixture of $\mathrm{Na}_{2} \mathrm{MoO}_{4} \cdot 2 \mathrm{H}_{2} \mathrm{O}$ and $\mathrm{Na}_{2} \mathrm{WO}_{4} \cdot 2 \mathrm{H}_{2} \mathrm{O}$ (Tianjin Bodi Chemistry Co., Ltd., analytically pure) with each metal concentration at $200 \mathrm{mg} / \mathrm{L}$ [44]. The length of the deposition period was varied between $0.5 \mathrm{~h}$ and $8.0 \mathrm{~h}$ to yield different Mo/W loadings. The amount of Mo and $\mathrm{W}$ loaded onto the graphite felt cathode, which varied from 0.00 to $0.48 \mathrm{mg} / \mathrm{cm}^{2}$, was estimated from the difference between the initial and the residual concentrations of Mo and $\mathrm{W}$ in solution. Based on the optimum $\mathrm{Mo} / \mathrm{W}$ loading, cathodes with different ratios of $\mathrm{Mo} / \mathrm{W}$ deposits were prepared through adjusting the amount of $\mathrm{Na}_{2} \mathrm{MoO}_{4} \cdot 2 \mathrm{H}_{2} \mathrm{O}$ and $\mathrm{Na}_{2} \mathrm{WO}_{4} \cdot 2 \mathrm{H}_{2} \mathrm{O}$ in the initial catholyte. The initial $\mathrm{pH}$ of the catholyte was set at 1.5 to facilitate efficient metals deposition $[44,47]$. After the completion of the metal deposition process, the cathodes were dried and calcined at $450{ }^{\circ} \mathrm{C}$ for $2 \mathrm{~h}$ in air to increase their photo response [48]. 
The photo-response curves were then measured in a solution of $0.1 \mathrm{M} \mathrm{Na}_{2} \mathrm{SO}_{4}$ at an illumination light intensity of $23.3 \mathrm{~mW} / \mathrm{cm}^{2}$ (wavelength range: $400-800 \mathrm{~nm}$ ) to characterize the photocatalytic properties of the electrodes.

\subsection{Operation of photo-assisted MFCs with Mo/W coated graphite felt cathodes}

The irradiated MFC cathodic chambers filled with $80 \mathrm{mg} / \mathrm{L}$ MNZ aqueous solution (Tianjin Bodi Chemistry Co., Ltd., analytically pure) were operated under either anaerobic conditions, obtained by continuous $\mathrm{N}_{2}$ sparging or under aerobic conditions through continuous air sparging, both at a rate of $80 \mathrm{~mL} / \mathrm{min}$ in the photo-assisted MFCs and Fenton-MFCs. Initial $\mathrm{pH}$ in the catholyte was always adjusted to 2.0 to favor both the in-situ $\mathrm{H}_{2} \mathrm{O}_{2}$ production $[44,47]$ and the Fenton oxidation reaction $[11,49]$.

The impact of Fenton-like reacting conditions on the rate of degradation and mineralization of MNZ, under aerobic conditions, was explored by adding $\mathrm{Fe}_{2}\left(\mathrm{SO}_{4}\right)_{3}$ (Sigma-Aldrich, analytically pure) to the catholyte at different Fe dosages of 5, 10 or $15 \mathrm{mg} / \mathrm{L}$.

The reactive species generated during the degradation and mineralization of MNZ in the photo-assisted MFCs and Fenton-MFCs were probed through radical scavenging experiments using ammonium oxalate (AO) for holes, isopropanol (IP) for $\bullet \mathrm{OH}$ and benzoquinone (BQ) for $\mathrm{O}_{2} \bullet^{-}$(Tianjin Bodi Chemistry Co., Ltd., analytically pure) $[50-51]$.

The catalytic stability of Mo/W coated cathodes was evaluated by conducting 
cycling experiments under the same conditions without further regeneration of the cathodes.

Control experiments in the MFCs were conducted using either the Mo/W coated graphite felt cathodes under darkness, or with irradiated bare graphite felt cathodes.

\subsection{Analytical and electrochemical methods}

The concentration of MNZ was measured by UV-spectroscopy at $\lambda_{\max }=318 \mathrm{~nm}$ using a UV-5500 PC spectrophotometer (Shanghai Metash Instruments Co., Ltd., China) $[7,12-13,15-16]$. The concentration of MNZ sampling from graphite felt cathodes of MFCs at an operational time of $1.0 \mathrm{~h}$ and determined by HPLC (46.2 \pm $0.1 \mathrm{mg} / \mathrm{L}$, Fig. S2A and B), matched the value determined by UV spectroscopy (46.3 $\pm 0.1 \mathrm{mg} / \mathrm{L}$, Fig. S2C) $(p=0.667>0.05)$, supporting the use of UV spectrophotoscopy for MNZ measurements.

The MNZ mineralization process in the catholyte and the organics consumed in the anolyte were monitored through the decay of the chemical oxygen demand (COD) [11], measured by standard methods using potassium permanganate as the oxidant [52]. The degradation and mineralization of MNZ in the catholyte were calculated according to Eq. $(10-11)(\%)$ or based on the net decrease in MNZ/COD concentrations divided by the operational time $(\mathrm{mg} / \mathrm{L} / \mathrm{h})$. The $C E_{\text {an }}(\%)$ was evaluated from Eq. (12) whereas mineralization current efficiency (\%) was calculated according to Eq. (13) [29].

Degradation $(\%)=\frac{C_{c a, 0}-C_{c a, t}}{C_{c a, 0}} \times 100 \%$ 
Mineralization $(\%)=\frac{C O D_{c a, 0}-C O D_{c a, t}}{C O D_{c a, 0}} \times 100 \%$

$C E_{a n}(\%)=\frac{\int_{0}^{t} I d t}{4 / 32 \times \mathrm{F} \times\left(C O D_{a n, 0}-C O D_{a n, t}\right) \times V_{a n}} \times 100 \%$

Mineralization current efficiency $(\%)=\frac{\mathrm{F} \times\left(C O D_{c a, 0}-C O D_{c a, t}\right) \times V_{c a}}{32 / 4 \times I \times t} \times 100 \%(13)$

where $C_{\mathrm{ca}, 0}(\mathrm{~g} / \mathrm{L})$ is the initial MNZ concentration in the catholyte, $C_{\mathrm{ca}, \mathrm{t}}(\mathrm{g} / \mathrm{L})$ is the MNZ concentration in the catholyte at operational time of $t(\mathrm{~s}) . C O D_{\mathrm{ca}, 0}(\mathrm{~g} / \mathrm{L})$ and $C O D_{\text {ca,t }}(\mathrm{g} / \mathrm{L})$ in the catholyte, and $C O D_{\mathrm{an}, 0}(\mathrm{~g} / \mathrm{L})$ and $C O D_{\mathrm{an}, \mathrm{t}}(\mathrm{g} / \mathrm{L})$ in the anolyte are the values of COD before and after treatment at operational time $t(\mathrm{~s})$, respectively. $V_{\text {an }}(\mathrm{L})$ and $V_{\text {ca }}(\mathrm{L})$ are the volumes of anolyte and catholyte, respectively. $I(\mathrm{~A})$ is the circuital current. F (96485 C/mole electron) is faraday constant.

A SEM (QUANTA450, FEI company, USA) equipped with a EDS (X-MAX 20 $\mathrm{mm}^{2}-50 \mathrm{~mm}^{2}$, Oxford Instruments, UK) was used to examine the morphologies of the electrodes coated with W and Mo. Liquid chromatography/mass spectrometry (LC/MS, G6224A, Agilent, USA) was used to validate the intermediate products of MNZ degradation in the catholyte. Prior to LC/MS analysis, the aqueous samples (20 $\mathrm{mL}$ ) were treated by solid-phase extraction using Dionex SolEx C18 columns. The columns were previously conditioned with $5 \mathrm{~mL}$ methyl alcohol followed by 5 $\mathrm{mL}$ ultrapure water. The samples were afterwards passed through the columns and the retained compounds were recovered by elution with $5 \mathrm{~mL}$ acetonitrile. The solvent of acetonitrile was finally evaporated with nitrogen to $1.0 \mathrm{~mL}$. The LC analysis was conducted by injecting $20 \mu \mathrm{L}$ samples with a mobile phase of $20: 80$ (v/v) acetonitrile/water mixture at $0.2 \mathrm{~L} / \mathrm{min}$. The MS was operated in negative/positive mode with electrospray source ionization (ESI) by applying 4.5 
$\mathrm{kV}$ interface voltage and $150.0 \mathrm{~V}$ Q-array $\mathrm{RF}$ voltage. The DL temperature was $250{ }^{\circ} \mathrm{C}$ and pure $\mathrm{N}_{2}$ was used as nebulizing and dryer gas [17].

The electrochemical performance of the photo-assisted MFCs was assessed by LSV, CV and EIS, conducted under either anaerobic or aerobic conditions. The potentials at the cathode and anode were monitored by a data logger using an automatic data acquisition system (PISO-813, Hongge Co., Taiwan). LSV was conducted at the open circuit potential (OCP) to $0 \mathrm{~V}$ using a potentiostat (BioLogic, VSP, France) at a scan rate of $0.1 \mathrm{mV} / \mathrm{s}$. Power and current densities were normalized to the geometric surface of the cathode. Energy recovery was calculated based on either the cathodic working volume $\left(\mathrm{kWh} / \mathrm{m}^{3}\right)$ or the unit mass of MNZ mineralized $(\mathrm{kWh} / \mathrm{kg} \mathrm{COD})$ [28,53-54]. $\mathrm{CV}$ was conducted from $-0.4 \mathrm{~V}$ to $0.7 \mathrm{~V}$ using a potentiostat (BioLogic, VSP, France) at a scan rate of $1.0 \mathrm{mV} / \mathrm{s}$. EIS was carried out at the frequency ranging from $100 \mathrm{kHz}$ to $0.01 \mathrm{~Hz}$ with a sinusoidal perturbation of 5 $\mathrm{mV}$ in amplitude at the cathodic OCP. Both CVs and EIS were performed in the catholyte using the same potentiostat with a three electrode system consisting of a working electrode, a SCE reference electrode and a Pt foil as counter electrode. The equivalent circuit and detailed values of different resistances were obtained through Zsimpwin software.

One-way ANOVA in SPSS 19.0 was used to analyze the differences among the data, and all of the data indicated significance levels of $P<0.05$.

\section{Results and discussion}




\subsection{Morphology and photoresponse of Mo/W catalysts deposited on graphite felts}

Figure 1 shows the SEM images and EDS analysis of the graphite felt cathodes with different $\mathrm{Mo} / \mathrm{W}$ loadings and molar ratios. Compared to the bare graphite felts (Fig. 1A), diverse nano-metric scale agglomerates were observed on the Mo/W loaded cathodes (Fig. 1B - E). Increasing the metal loadings from $0.08 \mathrm{mg} / \mathrm{cm}^{2}$ (Fig. 1B) to $0.18 \mathrm{mg} / \mathrm{cm}^{2}$ (Fig. 1C) increased the size of the Mo/W particles deposited on the graphite, whereas the Mo/W loading of $0.24 \mathrm{mg} / \mathrm{cm}^{2}$ exhibited very uniform and smooth micrometer sized spheres $(1.0-2.0 \mu \mathrm{m}$ in size) (Fig. 1D). Conversely, the loading of the cathodes with $0.48 \mathrm{mg} / \mathrm{cm}^{2}$ metals led to the formation of dense laminar deposits (Fig. 1E). The size and morphology of the different Mo/W loadings were crucial for determining the catalytic activity of the cathodes as shown in further sections.

At a same metal loading of $0.24 \mathrm{mg} / \mathrm{cm}^{2}$ and different $\mathrm{Mo} / \mathrm{W}$ molar ratios, the morphologies of the deposits were similarly smaller micrometer size spherical particles of $0.5-2.0 \mu \mathrm{m}$ in diameter $(\mathrm{Fig} .1 \mathrm{~F}-\mathrm{J})$. EDS confirmed the presence of the pure metals or binary mixtures of Mo/W with different metal ratios (Fig. 1K - O)

\section{Here Fig. 1}

The photocurrents determined in a conventional three-electrode electrochemical cell comprising the Mo/W deposited cathode as the working electrode (fixed at $0.4 \mathrm{~V}$ ), a Pt foil acted as counter electrode, and a SCE worked as the reference electrode was correlated to the morphological SEM observations. The photocurrent promptly increased under irradiation (Fig. S3) with optimal response observed at a $\mathrm{Mo} / \mathrm{W}$ 
loading of $0.24 \mathrm{mg} / \mathrm{cm}^{2}$ (Fig. S3A) and at a Mo/W ratio of $0.17: 1.0$ (Fig. S3B), while an excessive catalyst loading resulted in a decrease of the photocurrent. This shows that uniform and well distributed micrometer particles with $1.0-2.0 \mu \mathrm{m}$ in size were necessary to produce the highest photocurrents. In addition, Mo/W deposits with a higher content in $\mathrm{W}$ led to higher photocurrents. Large particle deposits and Mo/W ratios with Mo in excess suppressed the observed photocurrents.

\subsection{Impact of Mo/W loadings on MNZ degradation and mineralization in} photo-assisted MFCs under anaerobic or aerobic conditions

The results of preliminary experiments describing the time course of MNZ degradation and mineralization in photo-assisted MFCs at different catalyst loadings and Mo/W molar ratios under anaerobic or aerobic conditions are shown in Fig. S4. The faster degradation and mineralization kinetics were observed using the most responsive cathode electrode with a Mo/W loading of $0.24 \mathrm{mg} / \mathrm{cm}^{2}$ and a $\mathrm{Mo} / \mathrm{W}$ molar ratio of $0.17: 1.0$. MNZ degradation of $95.4 \pm 1.3 \%$ and mineralization of 13.3 $\pm 1.5 \%$ were reached in $30 \mathrm{~min}$ of reaction time under anaerobic conditions while $97.1 \pm 0.3 \%$ (degradation) and $73.1 \pm 1.8 \%$ (mineralization) were obtained in $60 \mathrm{~min}$ under aerobic conditions. Therefore, such operational times were used to analyze the kinetics of degradation and mineralization of MNZ in further experiments.

Figure 2 shows the results of MNZ degradation and mineralization and the $C E_{\text {an }}$ as a function of the cathode metal loading, under anaerobic or aerobic conditions. The degradation of MNZ (Fig. 2A and B) was favored under anaerobic conditions whereas 
aerobic conditions favored the mineralization of MNZ (Fig. 2C and D). The optimum Mo/W catalyst loadings were $0.24 \mathrm{mg} / \mathrm{cm}^{2}$ (anaerobic process) (Fig. 2A and C) and $0.18 \mathrm{mg} / \mathrm{cm}^{2}$ (aerobic process) (Fig. 2B and D). At these loadings, peaks in the $C E_{\text {an }}$ (Fig. 2E and F), mineralization current efficiency (Fig. S5A and B), circuital currents (Fig. S6) and power production (Fig. S7A) were observed as follows: Mo/W loading of $0.24 \mathrm{mg} / \mathrm{cm}^{2}$ (anaerobic): $43 \pm 2 \%, 33 \pm 3 \%, 0.7 \mathrm{~A} / \mathrm{m}^{2}, 93 \mathrm{~mW} / \mathrm{m}^{2}(0.0057$ $\mathrm{kWh} / \mathrm{m}^{3} ; 0.32 \mathrm{kWh} / \mathrm{kg} \mathrm{COD}$ ); Mo/W loading of $0.18 \mathrm{mg} / \mathrm{cm}^{2}$ (aerobic): $57 \pm 1 \%, 73$ $\pm 2 \%, 1.0 \mathrm{~A} / \mathrm{m}^{2}, 243 \mathrm{~mW} / \mathrm{m}^{2}\left(0.015 \mathrm{kWh} / \mathrm{m}^{3} ; 0.30 \mathrm{kWh} / \mathrm{kg}\right.$ COD $)$. The decrease of the oxidation rates at excessive Mo/W loadings was mainly ascribed to the complete coverage of the cathodic surface by excess and dense laminar Mo/W deposits, as shown in Fig. 1E.

The highest degree of MNZ mineralization of $61.8 \pm 2.5 \%(49.5 \pm 2.0 \mathrm{mg} / \mathrm{L} / \mathrm{h})$ was observed under aerobic conditions after $60 \mathrm{~min}$ of illumination time using a Mo/W loading of $0.18 \mathrm{mg} / \mathrm{cm}^{2}$ (Fig. 2D). This rate of MNZ mineralization was appreciably higher than the literature results obtained using other oxidation methods, such as, conventional electro-Fenton (10 mg/L/h at $\mathrm{pH} 2.0)$ [18], $\mathrm{Fe}^{0} / \mathrm{graphene}^{-\mathrm{TiO}_{2}}$ nanowires photocatalytic process (19.7 mg/L/h at $\mathrm{pH} 3.0)$ [12], bioanodes of MFCs $(0.4 \mathrm{mg} / \mathrm{L} / \mathrm{h}$ at $\mathrm{pH}$ 7.0) [55], and electrochemical reduction, electron-Fenton or photo-electro-Fenton processes $(0.5-14.3 \mathrm{mg} / \mathrm{L} / \mathrm{h}$ at $\mathrm{pH} 3.0-7.0)[4,5,9,17]$. Even using the bare graphite felt cathodes in the absence of catalysts and irradiation, cathodic reduction resulted in MNZ degradation of $44.7 \pm 1.3 \%(35.8 \pm 1.0 \mathrm{mg} / \mathrm{L} / \mathrm{h}$, anaerobic) and $40.8 \pm 1.1 \%(32.6 \pm 0.8 \mathrm{mg} / \mathrm{L} / \mathrm{h}$, aerobic $)$, ascribed to the superior 
performance of the graphite felt for the in-situ production of $\mathrm{H}_{2} \mathrm{O}_{2}[44,47]$.

Collectively, these results demonstrate the intensification of the degradation and mineralization of MNZ in the photo-assisted MFCs determined by a significant cooperative effect of Mo and W catalysts combined with $\mathrm{H}_{2} \mathrm{O}_{2}$ generated in-situ under aerobic conditions.

\section{Here Fig. 2}

The CVs (Fig. 3A and B) and EIS (an equivalent circuit in Fig. S8) (Fig. 3C and D) corroborated the results in Fig. 2. At the optimal Mo/W loading of $0.24 \mathrm{mg} / \mathrm{cm}^{2}$, the most positive onset reduction potentials (anaerobic: $0.02 \mathrm{~V}$, aerobic: $0.01 \mathrm{~V}$ ) and the highest reduction peak currents (anaerobic: $1.26 \mathrm{~mA}$, aerobic: $1.24 \mathrm{~mA}$ ) (Fig. 3A and $\mathrm{B})$ were observed, as well as, the lowest charge transfer resistances ( $R_{\mathrm{ct}}$, anaerobic: 16.9 $\Omega$, aerobic: $28.4 \Omega$ ) (Fig. 3C and D, Table S1) under both anaerobic (Fig. 3A and C) and aerobic (Fig. 3B and D) conditions. Furthermore, under aerobic conditions and at the optimal Mo/W loading of $0.18 \mathrm{mg} / \mathrm{cm}^{2}$, the highest oxidation peak current of $0.54 \mathrm{~mA}$ was observed at the most positive oxidation peak potential of $0.33 \mathrm{~V}$ (Fig. 3B), demonstrating that the most efficient oxidative reaction conditions were realized, consistent with the results shown in Fig. 2D.

The control experiments performed in the absence of metals using the bare graphite felt cathodes or in the presence of metals but in the absence of light irradiation, produced more negative onset reduction potentials, lower reduction peak currents, negligible onset oxidation potentials, lower oxidation peak currents, and higher $R_{\mathrm{ct}}$, under both anaerobic and aerobic conditions (Fig. 3 and Table S1). 
Therefore, intensified MNZ degradation and mineralization in the MFCs can be clearly realized by the cooperative effect of the Mo and W catalysts and light irradiation (Fig. 2A-D).

In all cases examined, anaerobic conditions (Fig. 3A and C, Table S1) always exhibited higher reduction peak currents and lower $R_{\mathrm{ct}}$, whereas aerobic conditions achieved higher oxidation peak currents with more positive oxidation peak potentials (Fig. 3B and D, Table S1). These results clearly demonstrate that anaerobic conditions were more effective for the reductive degradation of MNZ, while aerobic conditions were more influential for the mineralization of MNZ.

\section{Here Fig. 3}

\subsection{Impact of Mo/W molar ratios on MNZ degradation and mineralization in} photo-assisted MFCs under anaerobic or aerobic conditions

A binary mixture of W-Mo at a fixed loading of $0.24 \mathrm{mg} / \mathrm{cm}^{2}$ delivered higher MNZ degradation (Fig. 4A and B), MNZ mineralization (Fig. 4C and D), $C E_{\text {an }}$ (Fig. 4E and F) and mineralization current efficiency (Fig. S5C and D) in comparison to single metal loading, under both anaerobic (Fig. 4A, C and E) and aerobic (Fig. 4B, D and F) conditions. The lowest Mo/W molar ratio of $0.17: 1.0$ invariably achieved the higher rates of MNZ degradation and mineralization, under both anaerobic and aerobic conditions. The corresponding power productions were $104 \mathrm{~mW} / \mathrm{m}^{2}(0.0064$ $\mathrm{kWh} / \mathrm{m}^{3} ; 0.27 \mathrm{kWh} / \mathrm{kg}$ COD; anaerobic $)$ and $264 \mathrm{~mW} / \mathrm{m}^{2}\left(0.016 \mathrm{kWh} / \mathrm{m}^{3} ; 0.28\right.$ $\mathrm{kWh} / \mathrm{kg}$ COD; aerobic) (Fig. S7B). The MNZ mineralization of $73.1 \pm 1.8 \%(58.5 \pm$ 
$1.5 \mathrm{mg} / \mathrm{L} / \mathrm{h}$ ) under aerobic conditions was 7.5 times as high as the controls without $\mathrm{Mo} / \mathrm{W}$ deposits in the presence or absence of illumination light (Fig. 4D), 2.5 times under anaerobic conditions (Fig. 4C), and 1.3 times in the absence of illumination light but in the presence of Mo/W deposits (Fig. 4D). These results clearly reflect the cooperative effect of the Mo/W catalysts coupled with the in-situ cathodic production of $\mathrm{H}_{2} \mathrm{O}_{2}$ in the presence of light irradiation on the mineralization of MNZ. Such cooperative catalytic effect of Mo and $\mathrm{W}$ for the removal of other water contaminants has also been reported in other oxidation processes such as conventional photocatalysis or electrochemical processes [34-36].

As also observed in Fig. 2, the degradation of MNZ at different Mo/W molar ratios was favored under anaerobic conditions (Fig. 4A and B) whereas aerobic conditions favored the mineralization of MNZ (Fig. 4C and D). The consistency of higher MNZ degradation and mineralization with higher $C E_{\mathrm{an}}$ (Fig. 4E and F), mineralization current efficiency (Fig. S5C and D) and circuital currents (Fig. S9) at all tested ratios of Mo/W was also similar to those in Fig. 2E and F, and Fig. S6.

\section{Here Fig. 4}

The highest reduction peak currents (anaerobic: $1.76 \mathrm{~mA}$, aerobic: $1.41 \mathrm{~mA}$ ) and oxidation peak currents (anaerobic: $0.23 \mathrm{~mA}$, aerobic: $0.65 \mathrm{~mA}$ ) (Fig. $5 \mathrm{~A}$ and B) as well as the lowest $R_{\mathrm{ct}}$ (anaerobic: $9.8 \Omega$, aerobic: $22.3 \Omega$ ) (Fig. $5 \mathrm{C}$ and D, Table S1) were invariably observed at a Mo/W ratio of $0.17: 1.0$ under both anaerobic (Fig. 5A and C, Table S1) and aerobic (Fig. 5B and D, Table S1) conditions. These results confirm this to be an optimal Mo/W ratio for the degradation and mineralization of 
MNZ. The CV results demonstrated that, at each $\mathrm{Mo} / \mathrm{W}$ ratios, higher reduction peak currents were always observed under anaerobic (Fig. 5A) rather than aerobic (Fig. 5B) conditions. Conversely, aerobic (Fig. 5B) rather than anaerobic (Fig. 5A) conditions achieved higher oxidation peak currents at each Mo/W ratios, demonstrating the more favorable aerobic rather than anaerobic conditions for MNZ oxidation degradation (mineralization). These results corroborated with the results in Figs. 2 - 4 .

\section{Here Fig. 5}

\subsection{Intensification of system performance in the presence of $\mathrm{Fe}(I I I)$ under aerobic} conditions

The oxidation of MNZ in the photo-assisted MFCs can be further intensified by the production of $\bullet \mathrm{OH}$ by combining the catalytic photo-Fenton and an electro-Fenton processes, in the presence of supplementary Fe(III) species in the system. In this mechanism, the photoreduction of $\mathrm{Fe}(\mathrm{III})$ to $\mathrm{Fe}(\mathrm{II})$ results in the generation of $\bullet \cdot \mathrm{OH}$ and $\mathrm{Fe}(\mathrm{II})$. As a consequence, the produced $\mathrm{Fe}(\mathrm{II})$ species further react with $\mathrm{H}_{2} \mathrm{O}_{2}$ in-situ generated at the cathode to produce supplementary $\bullet \mathrm{OH}$ and $\mathrm{Fe}(\mathrm{III})$ species, closing the catalytic cycle.

The results of experiments performed at different Fe(III) dosages are shown in Fig. 6. The highest rates of MNZ degradation of $94.5 \pm 1.4 \%(75.6 \pm 1.1 \mathrm{mg} / \mathrm{L} / \mathrm{h})($ Fig. $6 \mathrm{~A})$ and mineralization of $89.5 \pm 1.1 \%(71.6 \pm 0.9 \mathrm{mg} / \mathrm{L} / \mathrm{h})($ Fig. $6 \mathrm{~B})$ obtained after 60 min were observed using $10 \mathrm{mg} / \mathrm{L}$ of $\mathrm{Fe}(\mathrm{III})$. This MNZ mineralization was appreciably higher than $67.7 \pm 2.2 \%(54.1 \pm 1.8 \mathrm{mg} / \mathrm{L} / \mathrm{h})$ with electron-Fenton and 
$77.7 \pm 1.8 \%(62.2 \pm 1.5 \mathrm{mg} / \mathrm{L} / \mathrm{h})$ in photo-assisted MFCs only (Fig. 6B). The associated power production at the $\mathrm{Fe}(\mathrm{III})$ of $10 \mathrm{mg} / \mathrm{L}$ was $251 \mathrm{~mW} / \mathrm{m}^{2}(0.015$ $\mathrm{kWh} / \mathrm{m}^{3} ; 0.22 \mathrm{kWh} / \mathrm{kg}$ COD) (Fig. S10).

However, excessive $\mathrm{Fe}(\mathrm{III})$ at a dosage of $15 \mathrm{mg} / \mathrm{L}$ decreased the mineralization of MNZ, ascribed to the simultaneous consumption of $\bullet \mathrm{OH}$ by an excessive amount of $\mathrm{Fe}(\mathrm{II})$ in the catholyte which was derived from cathodic $\mathrm{Fe}(\mathrm{III})$ reduction and can act as an reductive agent $[9,17]$. The MNZ mineralization rate observed under optimized conditions $(89.5 \pm 1.1 \%, 71.6 \pm 0.9 \mathrm{mg} / \mathrm{L} / \mathrm{h})$ was significantly higher than the 12.0 $\mathrm{mg} / \mathrm{L} / \mathrm{h}$ observed in conventional electro-Fenton process at the same $\mathrm{pH}$ of 2.0 with an external applied current of $0.7 \mathrm{~A} / \mathrm{m}^{2}$ [18], and $25.4-50.0 \mathrm{mg} / \mathrm{L} / \mathrm{h}$ determined in photocatalytic processes using catalysts of $\mathrm{Fe}^{0} / \mathrm{graphene}-\mathrm{TiO}_{2}$, nano- $\mathrm{ZnO}$ or $\mathrm{TiO}_{2} / \mathrm{ZnIn}_{2} \mathrm{~S}_{4}[12,14,16]$.

The presence of $\mathrm{Fe}(\mathrm{III})$ in the catholyte increased the circuital currents (Fig. S11) and thus the $C E_{\text {an }}$ (Fig. 6C) and the mineralization current efficiency (Fig. S12), compared to the control experiments performed in the absence of $\mathrm{Fe}(\mathrm{III})$, mainly explained by the presence of more electron acceptors in the catholyte [40,56-58].

\section{Here Fig. 6}

3.5 Detection of active reacting species by scavengers, and possible MNZ degradation and mineralization pathways

The reactive species generated during the degradation and mineralization of MNZ in the photo-assisted MFCs and Fenton-MFCs were probed through radical 
scavenging experiments. Under anaerobic conditions, the addition of AO (hole scavenger) to the aqueous solution decreased MNZ degradation (Fig. 7A), confirming the direct participation of photo-generated holes. The direct involvement of holes was also observed for the oxidation of the intermediate products of MNZ reduction under anaerobic conditions since the presence of $\mathrm{AO}$ resulted in an increase in the UV-absorption peak at $200-240 \mathrm{~nm}$ [2] (Fig. 7B). The presence of $\bullet O H$ radicals was excluded since the presence of IP $(\bullet \mathrm{OH}$ scavenger $)$ negligibly changed the rate of MNZ degradation (Fig. 7A) and the peak height at $200-240 \mathrm{~nm}$ of the reaction intermediates (Fig. 7B), indicating that $\cdot \mathrm{OH}$ was not an active species in both $\mathrm{MNZ}$ degradation and mineralization, under anaerobic conditions. In the control experiments under aerobic conditions, under darkness and in the absence of Fe(III), however, the presence of IP diminished the MNZ degradation (Fig. 7A) and increased the peak height at $200-240 \mathrm{~nm}$ (Fig. 7C), confirming the production of $\bullet \mathrm{OH}$ radicals through the decomposition of in-situ generated $\mathrm{H}_{2} \mathrm{O}_{2}$ [9,17-18].

In direct contrast, the dominant active species for the cleavage of MNZ and for the oxidation of the intermediate products, under aerobic conditions, were the superoxide radical $\left(\mathrm{O}_{2} \bullet^{-}\right)$, since strong inhibition of MNZ degradation (58.8 $\pm 0.8 \%$, Fig. 7A) and the highest peak height at $200-240 \mathrm{~nm}$ (Fig. 7D) were observed in the presence of BQ (superoxide scavenger). The $\bullet \mathrm{OH}$ was also a participating species under aerobic conditions, since a slight decrease in MNZ degradation (Fig. 7A) and a slight increase in peak height at $200-240 \mathrm{~nm}$ (Fig. 7D) were observed in the presence of IP. However, under aerobic conditions and in the presence of $\mathrm{Fe}(\mathrm{III})$, the 
direct participation of $\bullet \mathrm{OH}$ was predominant to $\mathrm{O}_{2} \bullet^{-}$(the reverse situation found in the absence of $\mathrm{Fe}(\mathrm{III})$ ) since the inhibition of MNZ degradation (Fig. 7A) and the peak height at $200-240 \mathrm{~nm}$ (Fig. 7E) were more accentuated in the presence of IP rather than BQ. The direct participation of holes under aerobic conditions, with or without the presence of $\mathrm{Fe}(\mathrm{III})$, was excluded since negligible impacts on the rate of MNZ degradation (Fig. 7A) and on the peak height at $200-240 \mathrm{~nm}$ (Fig. 7D and E) were observed in the presence of AO.

\section{Here Fig. 7}

The mechanism of degradation of MNZ in the photo-assisted MFCs was further elucidated by LC-MS analysis of reaction intermediates formed under anaerobic and aerobic conditions (Fig. 8). The intermediate with amino group under both anaerobic and aerobic conditions [(-)ESI: 140; (+)ESI: 142] (Fig. 8A - C) implies the nitro-reduction of MNZ, consistent with the observations in conventional electrochemical degradation of MNZ [4]. The intermediates at $\mathrm{m} / \mathrm{z}=126$ (Fig. 8A and B) and 155 (Fig. 8C and D) observed under anaerobic (Fig. 8A and C) and aerobic (Fig. 8B and D) conditions imply the pathways of either denitrification and the subsequent hydroxylation or the loss of lateral N-ethanol group via oxidized $\mathrm{N}$-acetoxy, as frequently reported in conventional photocatalysis or photoelectro processes $[8,12,17]$. The preferential presence of 4-methyl imidazole $(\mathrm{m} / \mathrm{z}=83)$ under aerobic, rather than anaerobic conditions, also previously observed in a photocatalytic process [8], supports the preferable oxidation of MNZ through the loss of the lateral hydroxy and nitro group. The cleavage intermediate $(\mathrm{m} / \mathrm{Z}=116)$ under both anaerobic 
and aerobic conditions (Fig. 8C and D) as previously found in a conventional photocatalytic process [59], proves the occurrence of MNZ mineralization with variable degrees, consistent with the results in Figs. 2 and 4.

\section{Here Fig. 8}

On the basis of the radical scavenging results and the analysis of the reaction intermediates by LC-MS, the reaction scheme shown in Fig. 9 is proposed for the degradation and mineralization of MNZ in the photo-assisted MFCs with Mo/W catalytic cathodes under anaerobic or aerobic conditions

\section{Here Fig. 9}

\subsection{Lifetime of Mo/W loaded cathodes}

The stability of the graphite felt cathodes loaded with the optimal amount and $\mathrm{Mo} / \mathrm{W}$ molar ratio was investigated in consecutive batch MNZ oxidation cycles in the photo-assisted MFCs in the presence of the optimal dose of Fe(III) (Fig. 10). Under anaerobic conditions, the degradation of MNZ slightly decreased by $7.7 \%$ after 10 operational cycles, whereas the mineralization of MNZ remained practically unchanged (Fig. 10A). Under aerobic conditions, a slight decrease of 7.9\% (MNZ degradation) and 10.4\% (MNZ mineralization) was observed (Fig. 10B). These results were mirrored by a decay of the circuital current and $C E_{\text {an }}$ of the same order of magnitude, after the $10^{\text {th }}$ operational cycle (Fig. 10C and D). Overall, the performance of the photo-assisted MFCs intensified by the use of Mo and W catalytic species and Fe (III) can be considered promising for utilization in environmental remediation and 
contaminated streams with simultaneous production of renewable energy.

\section{Here Fig. 10}

In summary, the comprehensive results presented in this study through multiple characterization methods demonstrate the efficient and environmentally benign approach of hybrid photo-assisted MFCs and Fenton-MFCs for the intensification of the removal of the antibiotic MNZ in water and possibly other contaminants of emerging concern with simultaneous renewable electricity generation. In this system Mo and W catalytic species immobilized onto a graphite felt cathode intensified the cathodic reduction of MNZ under anaerobic conditions and the oxidation of MNZ under aerobic conditions, with the latter further accelerated in the presence of $\mathrm{Fe}(\mathrm{III})$. Photo-generated holes were directly involved into the oxidation of MNZ under anaerobic conditions. Conversely, under aerobic conditions, the photo-generated electrons favored the production of $\mathrm{O}_{2} \bullet^{-}$over $\bullet \mathrm{OH}$, while in the presence of $\mathrm{Fe}(\mathrm{III})$, -OH was predominant over $\mathrm{O}_{2} \bullet^{-}$, explaining the intensification of the $\mathrm{MNZ}$ mineralization observed. A schematic representation of the above mechanism is shown in Fig. 11.

\section{Here Fig. 11}

The practical application of the combined photo-assisted MFCs and Fenton-MFCs process for degradation and mineralization of contaminants of emerging concern is favored by the use of the two-chamber MFC system, which in contrast to the one-chamber system allow the simultaneous treatment of two different wastewaters and the control over the toxicity of the water contaminants to the anodic 
exoelectrogens species [38-41,56-58,60]. However, the practical implementation of this technology for industrial wastewater treatment requires further pilot and full-scale investigations, to evaluate the long-term operation and stability of the system over a feed with fluctuating characteristics and the process economics [54,58,61-63].

\section{Conclusions}

This study has demonstrated the intensification of process for the removal of a common antibiotic in water with simultaneous production of renewable electrical energy. This was achieved in MFCs operated with irradiated graphite felt cathodes loaded with optimal amounts of $\mathrm{Mo}$ and $\mathrm{W}$ species. The degradation and mineralization of MNZ can be further accelerated by the presence of $\mathrm{Fe}(\mathrm{III})$ species, realizing the integration of a photo-assisted MFCs and a Fenton-MFCs in a single system. An operational strategy can be envisaged utilizing a sequential anaerobic process that favors the reductive degradation of antibiotics, followed by an aerobic process in the presence of $\mathrm{Fe}(\mathrm{III})$ that facilitates the mineralization of antibiotics and other contaminants of emerging concern in water and wastewater.

\section{Acknowledgments}

The authors gratefully acknowledge financial support from the National Natural Science Foundation of China (Nos. 51578104 and 21777017).

\section{References}

[1] A. Chatzitakis, C. Berberidou, I. Paspaltsis, G. Kyriakou, T. Sklaviadis, I. Poulios, Photocatalytic degradation and drug activity reduction of chloramphenicol, Water Res. 42 (2008) 386-394. 
[2] Z. Fang, X. Qiu, J. Chen, X. Qiu, Degradation of metronidazole by nanoscale zero-valent metal prepared from steel pickling waste liquor, Appl. Catal. B Environ. 100 (2010) 221-228.

[3] M. Farzadkia, E. Bazrafshan, A. Esrafili, J.K. Yang, M. Shirzad-Siboni, Photocatalytic degradation of metronidazole with illuminated $\mathrm{TiO}_{2}$ nanoparticles, J. Environ. Health Sci. Eng. 13 (2015) 35.

[4] D. Kong, B. Liang, H. Yun, H. Cheng, J. Ma, M. Cui, A. Wang, N. Ren, Cathodic degradation of antibiotics: Characterization and pathway analysis, Water Res. 72 (2015) 281-292.

[5] Q. Dai, J. Zhou, M. Weng, X. Luo, D. Feng, J. Chen, Electrochemical oxidation metronidazole with Co modified $\mathrm{PbO}_{2}$ electrode: Degradation and mechanism, Sep. Purif. Technol. 166 (2016) 109-116.

[6] F. Mansour, M. Al-Hindi, R. Yahfoufi, G.M. Ayoub, M.N. Ahmad, The use of activated carbon for the removal of pharmaceuticals from aqueous solutions: a review, Rev. Environ. Sci. Biotechnol. 17 (2018) 109-145.

[7] X. Zhao, S. Su, G. Wu, C. Li, Z. Qin, X. Lou, Facile synthesis of the flower-like ternary heterostructure of $\mathrm{Ag} / \mathrm{ZnO}$ encapsulating carbon spheres with enhanced photocatalytic performance, Appl. Surf. Sci. 406 (2017) 254-264.

[8] L. Tong, S. Pérez, C. Gonçalves, F. Alpendurada, Y. Wang, D. Barceló, Kinetic and mechanistic studies of the photolysis of metronidazole in simulated aqueous environmental matrices using a mass spectrometric approach, Anal. Bioanal. Chem. 399 (2011) 421-428.

[9] W. Cheng, M. Yang, Y. Xie, B. Liang, Z. Fang, E.P. Tsang, Enhancement of mineralization of metronidazole by the electro-Fenton process with a $\mathrm{Ce} / \mathrm{SnO}_{2}-\mathrm{Sb}$ coated titanium anode, Chem. Eng. J. 220 (2013) 214-220.

[10] H.B. Ammar, M.B. Brahim, R. Abdelhédi, Y. Samet, Enhanced degradation of metronidazole by sunlight via photo-Fenton process under gradual addition of hydrogen peroxide, J. Mol. Catal. A Chem. 420 (2016) 222-227.

[11] G. Boczkaj and A. Fernandes, Wastewater treatment by means of advanced oxidation processes at basic $\mathrm{pH}$ conditions: A review, Chem. Eng. J. 320 (2017) 608-633.

[12] X. Wang, A. Wang, M. Lu, J. Ma, Synthesis of magnetically recoverable $\mathrm{Fe}-0 /$ graphene- $\mathrm{TiO}_{2}$ nanowires composite for both reduction and photocatalytic oxidation of metronidazole, Chem. Eng. J. 337 (2018) 372-384.

[13] S. Dong, J. Sun, Y. Li, C. Yu, Y. Li, J. Sun, $\mathrm{ZnSnO}_{3}$ hollow nanospheres/reduced grapheme oxide nanocomposites as high-performance photocatalysts for degradation of metronidazole, Appl. Catal. B Environ. 144 (2014) 386-393.

[14] M. Farzadkia, A. Esrafili, M. Ali Baghapour, Y Dadban Shahamat, N. Okhovat, Degradation of metronidazole in aqueous solution by nano- $\mathrm{ZnO} / \mathrm{UV}$ photocatalytic process, Desalin. Water Treat. 52 (2014) 4947-4952.

[15] H. Derikvandi and A. Nezamzadeh-Ejhieh, Synergistic effect of p-n heterojunction, supporting and zeolite nanoparticles in enhanced photocatalytic activity of $\mathrm{NiO}$ and $\mathrm{SnO}_{2}$, J. Colloid. Interf. Sci. 490 (2017) 314-327.

[16] Y. Xia, Q. Li, K. Lv, M. Li, Heterojunction construction between $\mathrm{TiO}_{2}$ 
hollowsphere and $\mathrm{ZnIn}_{2} \mathrm{~S}_{4}$ flower for photocatalysis application, Appl. Surf. Sci. 398 (2017) 81-88.

[17] T. Pérez, S. Garcia-Segura, A. El-Ghenymy, J.L. Nava, E. Brillas, Solar photoelectro-Fenton degradation of the antibiotic metronidazole using a flow plant with a Pt/air-diffusion cell and a CPC photoreactor, Electrochim. Acta 165 (2015) 173-181.

[18] A. Aboudalle, F. Fourcade, A. Amin Assadi, L. Domergue, H. Djelal, T. Lendormi, S. Taha, A. Amrane, Reactive oxygen and iron species monitoring to investigate the electro-Fenton performances. Impact of the electrochemical process on the biodegradability of metronidazole and its by-products, Chemosphere 199 (2018) 486-494.

[19] H. Han, C. Shi, L. Yuan, G. Sheng, Enhancement of methyl orange degradation and power generation in a photoelectrocatalytic microbial fuel cell, Appl. Energ. 204 (2017) 382-389.

[20] C. Jiang, L. Liu, J.C. Crittenden, An electrochemical process that uses an $\mathrm{Fe} 0 / \mathrm{TiO}_{2}$ cathode to degrade typical dyes and antibiotics and a bio-anode that produces electricity, Front. Environ. Sci. Eng. 10 (2016) 15.

[21] D. Zhou, S. Dong, D. Ki, B.E. Rittmann, Photocatalytic-induced electron transfer via anode-respiring bacteria (ARB) at an anode that intimately couples ARB and a $\mathrm{TiO}_{2}$ photocatalyst, Chem. Eng. J. 338 (2018) 745-751.

[22] L. Zhuang, S. Zhou, Y. Yuan, M. Liu, Y. Wang, A novel bioelectro-Fenton system for coupling anodic COD removal with cathodic dye degradation, Chem. Eng. J. 163 (2010) 160-163.

[23] M. Hassan, N. Pous, B. Xie, J. Colprim, M. Dolors Balaguer, S. Puig, Influence of iron species on integrated microbial fuel cell and electro-Fenton process treating landfill leachate, Chem. Eng. J. 328 (2017) 57-65.

[24] Y. Wang, C. Feng, Y. Li, J. Gao, C.P. Yu, Enhancement of emerging contaminants removal using Fenton reaction driven by $\mathrm{H}_{2} \mathrm{O}_{2}$-producing microbial fuel cells, Chem. Eng. J. 307 (2017) 679-686.

[25] Y.T. Wang and R.S. Wang, A bio-electro-Fenton system employing the composite FePc/CNT/SS316 cathode, Materials 10 (2017) 169.

[26] M. Kahoush, N. Behary, A. Cayla, V. Nierstrasz, Bio-Fenton and bio-electro-Fenton as sustainable methods for degrading organic pollutants in wastewater, Process Biochem. 64 (2018) 237-247.

[27] M. Panizza and G. Cerisola, Direct and mediated anodic oxidation of organic pollutants, Chem. Rev. 109 (2009) 6541-6569.

[28] E. Brillas and C.A. Martínez-Huitle, Decontamination of wastewaters containing synthetic organic dyes by electrochemical methods. An updated review, Appl. Catal. B Environ. 166-167 (2015) 603-643.

[29] C.A. Martínez-Huitle, M.A. Rodrigo, I. Sirés, O. Scialdone, Single and coupled electrochemical processes and reactors for the abatement of organic water pollutants: A critical review, Chem. Rev. 115 (2015) 13362-13407.

[30] I. Sirés, E. Brillas, M.A. Oturan, M.A. Rodrigo, M. Panizza, Electrochemical advanced oxidation processes: today and tomorrow. A review. Environ. Sci. 
Pollut. Res. 21 (2014) 8336-8367.

[31] H. Ding, Y. Li, A. Lu, S. Jin, C. Quan, C. Wang, X. Wang, C. Zeng, Y. Yan, Photocatalytically improved azo dye reduction in a microbial fuel cell with rutile-cathode, Bioresour. Technol. 101 (2010) 3500-3505.

[32] Q. Zhao, H. Yu, W. Zhang, F.T. Kabutey, J. Jiang, Y. Zhang, K. Wang, J. Ding, Microbial fuel cell with high content solid wastes as substrates: a review, Front. Environ. Sci. Eng. 11 (2017) 13.

[33] D. Robert, Photosensitization of $\mathrm{TiO}_{2}$ by $\mathrm{M}_{\mathrm{x}} \mathrm{O}_{\mathrm{y}}$ and $\mathrm{M}_{\mathrm{x}} \mathrm{S}_{\mathrm{y}}$ nanoparticles for heterogeneous photocatalysis applications, Catal. Today 122 (2007) 20-26.

[34] L. Zhou, J. Zhu, M. Yu, X. Huang, Z. Li, Y. Wang, C. Yu, $\mathrm{Mo}_{\mathrm{x}} \mathrm{W}_{1-\mathrm{x}} \mathrm{O}_{3} \cdot 0.33 \mathrm{H}_{2} \mathrm{O}$ solid solutions with tunable band gaps, J. Phys. Chem. C 114 (2010) 20947-20954.

[35] Y. Zhou, W. Li, W. Wan, R. Zhang, Y. Lin, W/Mo co-doped $\mathrm{BiVO}_{4}$ for photocatalytic treatment of polymer-containing wastewater in oilfield, Superlattice Microst. 82 (2015) 67-74.

[36] A. Arzola-Rubio, J. Camarillo-Cisneros, L. Fuentes-Cobas, V. Collins-Martínez, L. De la Torre-Sáenz, F. Paraguay-Delgado, Enhanced optical properties of $\mathrm{W}_{1-\mathrm{x}} \mathrm{Mo}_{\mathrm{x}} \mathrm{O}_{3} \cdot 0.33 \mathrm{H}_{2} \mathrm{O}$ solid solutions with tunable band gaps, Superlattice Microst. 81 (2015) 175-184.

[37] Z. Zhang, J. Liu, J. Gu, L. Su, L. Cheng, An overview of metal oxide materials as electrocatalysts and supports for polymer electrolyte fuel cells, Energy Environ. Sci. 7 (2014) 2535-2558.

[38] L. Huang, Q. Wang, X. Quan, Y. Liu, G. Chen, Bioanodes/biocathodes formed at optimal potentials enhance subsequent pentachlorophenol degradation and power generation from microbial fuel cells, Bioelectrochemistry 94 (2013) 13-22.

[39] L. Huang, M. Li, Y. Pan, Y. Shi, X. Quan, G. Li Puma, Efficient W and Mo deposition and separation with simultaneous hydrogen production in stacked bioelectrochemical systems, Chem. Eng. J. 327 (2017) 584-596.

[40] J. Shen, L. Huang, P. Zhou, X. Quan, G. Li Puma, Correlation between circuital current, $\mathrm{Cu}$ (II) reduction and cellular electron transfer in EAB isolated from $\mathrm{Cu}(\mathrm{II})$-reduced biocathodes of microbial fuel cells, Bioelectrochemistry 114 (2017) 1-7.

[41] L. Huang, Z. Lin, X. Quan, Q. Zhao, W. Yang, B.E. Logan, Efficient in-situ utilization of caustic for sequential recovery and separation of $\mathrm{Sn}, \mathrm{Fe}$, and $\mathrm{Cu}$ in microbial fuel cells, ChemElectroChem 5 (2018) 1658-1669.

[42] W.F. Cai, J.F. Geng, K.B. Pu, Q. Ma, D.W. Jing, Y.H. Wang, Q.Y. Chen, H. Liu, Investigation of a two-dimensional model on microbial fuel cell with different biofilm porosities and external resistances, Chem. Eng. J. 333 (2018) 572-582.

[43] Q. Wang, L. Huang, H. Yu, X. Quan, Y. Li, G. Fan, L. Li, Assessment of five different cathode materials for Co(II) reduction with simultaneous hydrogen evolution in microbial electrolysis cells, Inter. J. Hydrogen Energy 40 (2015) 184-196.

[44] Q. Wang, L. Huang, X. Quan, Q. Zhao, Preferable utilization of in-situ produced $\mathrm{H}_{2} \mathrm{O}_{2}$ rather than externally added for efficient deposition of tungsten and 
molybdenum in microbial fuel cells, Electrochim. Acta 247 (2017) 880-890.

[45] H. Zheng, J.Z. Ou, M.S. Strano, R.B. Kaner, A. Mitchell, K. Kalantar-zadeh, Nanostructured tungsten oxide - properties, synthesis, and applications, Adv. Funct. Mater. 21 (2011) 2175-2196.

[46] L. Mai, F. Yang, Y. Zhao, X. Xu, L. Xu, B. Hu, Y. Luo, H. Liu, Molybdenum oxide nanowires synthesis \& properties, Mater. Today 14 (2011) 346-353.

[47] Q Wang, L Huang, X Quan, Q Zhao, Cooperative light irradiation and in-situ produced $\mathrm{H}_{2} \mathrm{O}_{2}$ for efficient tungsten and molybdenum deposition in microbial electrolysis cells, J. Photochem. Photobiol. A Chem. 357 (2018) 156-167.

[48] S.H. Baeck, K.S. Choi, T.F. Jaramillo, G.D. Stucky, E.W. McFarland, Enhancement of photocatalytic and electrochromic properties of electrochemically fabricated mesoporous $\mathrm{WO}_{3}$ thin films, Adv. Mater. 15 (2003) 1269-1273.

[49] M. Gągol, A. Przyjazny, G. Boczkaj, Wastewater treatment by means of advanced oxidation processes based on cavitation-A review, Chem. Eng. J. 338 (2018) 599-627.

[50] R. Cai, B. Zhang, J. Shi, M. Li, Z. He, Rapid photocatalytic decolorization of methyl orange under visible light using VS4/carbon powder nanocomposites, ACS Sustain. Chem. Eng. 5 (2017) 7690-7699.

[51] B. Zhang, S. Zou, R. Cai, M. Li, Z. He, Highly-efficient photocatalytic disinfection of Escherichia coli under visible light using carbon supported vanadium tetrasulfide nanocomposites, Appl. Catal. B Environ. 224 (2018) 383-393.

[52] State Environment Protection Administration, the Water and Wastewater Monitoring Methods, $4^{\text {th }}$ ed., China Environmental Science Press, Beijing, 2002.

[53] S. Zou and Z. He, Efficiently "pumping out" value-added resources from wastewater by bioelectrochemical systems: A review from energy perspectives, Water Res. 131 (2018) 62-73.

[54] A. Jain and Z. He, "NEW" resource recovery from wastewater using bioelectrochemical systems: Moving forward with functions, Front. Environ. Sci. Eng. 12 (2018) 1.

[55] H. Song, W. Guo, M. Liu, J. Sun, Performance of microbial fuel cells on removal of metronidazole, Water Sci. Technol. 68 (2013) 2599-2604.

[56] L. Huang, L. Gan, N. Wang, X. Quan, B.E. Logan, G. Chen, Mineralization of pentachlorophenol with enhanced degradation and power generation from air cathode microbial fuel cells, Biotechnol. Bioeng. 109 (2012) 2211-2221.

[57] L. Huang, P. Zhou, X. Quan, B.E. Logan, Removal of binary $\mathrm{Cr}(\mathrm{VI})$ and $\mathrm{Cd}(\mathrm{II})$ from the catholyte of MFCs and determining their fate in EAB using fluorescence probes, Bioelectrochemistry 122 (2018) 61-68.

[58] X. Dominguez-Benetton, J. Chandrakant Varia, G. Pozo, O. Modin, A. ter Heijne, J. Fransaer, K. Rabaey, Metal recovery by microbial electro-metallurgy, Prog. Mater. Sci. 94 (2018) 435-461.

[59] N. Neghi and K. Mathava, Performance analysis of photolytic, photocatalytic, and adsorption systems in the degradation of metronidazole on the perspective of 
removal rate and energy consumption, Water Air Soil Pollut. 228 (2017) 339.

[60] Y. Zhang, L. Yu, D. Wu, L. Huang, P. Zhou, X. Quan, G. Chen, Dependency of simultaneous $\mathrm{Cr}(\mathrm{VI}), \mathrm{Cu}(\mathrm{II})$ and $\mathrm{Cd}(\mathrm{II})$ reduction on the cathodes of microbial electrolysis cells self-driven by microbial fuel cells, J. Power Sources 273 (2015) 1103-1113.

[61] W. Li, H. Yu, Z. He, Towards sustainable wastewater treatment by using microbial fuel cells-centered technologies, Energy Environ. Sci. 7 (2014) 911-924.

[62] X. Liu, W. Li, H. Yu, Cathodic catalysts in bioelectrochemical systems for energy recovery from wastewater, Chem. Soc. Rev. 43 (2014) 7718-7745.

[63] S. Ren, M. Li, J. Sun, Y. Bian, K. Zuo, X. Zhang, P. Liang, X. Huang, A novel electrochemical reactor for nitrogen and phosphorus recovery from domestic wastewater, Front. Environ. Sci. Eng. 11 (2017) 17.

Fig. 1 SEM observation on the graphite felt cathodes with Mo/W loading of 0.00 $\mathrm{mg} / \mathrm{cm}^{2}$ (A), $0.08 \mathrm{mg} / \mathrm{cm}^{2}$ (B), $0.18 \mathrm{mg} / \mathrm{cm}^{2}$ (C), $0.24 \mathrm{mg} / \mathrm{cm}^{2}$ (D) or 0.48 $\mathrm{mg} / \mathrm{cm}^{2}(\mathrm{E})$ at a same Mo/W ratio of $2.33: 1.0$. SEM observation $(\mathrm{F}, \mathrm{G}, \mathrm{H}, \mathrm{I}$ and $\mathrm{J})$ and $\mathrm{EDS}$ analysis (K, L, M, N and $\mathrm{O}$ ) on the cathodes at $\mathrm{Mo} / \mathrm{W}$ ratios of only Mo (F and $\mathrm{K}), 6.33: 1.0$ (G and L), $2.33: 1.0(\mathrm{H}$ and $\mathrm{M}), 0.17: 1.0(\mathrm{I}$ and $\mathrm{N})$, and only $\mathrm{W}$ ( $\mathrm{J}$ and $\mathrm{O}$ ) with fixed metal loading of $0.24 \mathrm{mg} / \mathrm{cm}^{2}$.

Fig. $2 \mathrm{MNZ}$ degradation (A and $\mathrm{B}$ ) and mineralization (C and $\mathrm{D})$, and anodic coulombic efficiency $\left(C E_{\text {an }}\right)(\mathrm{E}$ and $\mathrm{F})$ as a function of metal loading under anaerobic (A, C and $\mathrm{E}$ ) or aerobic $(\mathrm{B}, \mathrm{D}$ and $\mathrm{F})$ conditions $(\mathrm{Mo} / \mathrm{W}$ ratio of 2.33 : $1.0)$.

Fig. $3 \mathrm{CVs}$ (A and B) and EIS (C and D) on the electrode as a function of metal loading amount under anaerobic (A and $\mathrm{C}$ ) or aerobic (B and $\mathrm{D})$ conditions.

Fig. $4 \mathrm{MNZ}$ degradation (A and $\mathrm{B}$ ) and mineralization (C and D), and anodic coulombic efficiency $\left(C E_{\mathrm{an}}\right)(\mathrm{E}$ and $\mathrm{F})$ as a function of molar ratio of $\mathrm{Mo} / \mathrm{W}$ at a fixed metal loading of $0.24 \mathrm{mg} / \mathrm{cm}^{2}$ under anaerobic (A, C and $\mathrm{E}$ ) or aerobic (B, $\mathrm{D}$ and $\mathrm{F})$ conditions.

Fig. 5 CVs (A and B) and EIS (C and D) on the electrode as a function of $\mathrm{Mo} / \mathrm{W}$ ratio at a fixed metal loading of $0.24 \mathrm{mg} / \mathrm{cm}^{2}$ under anaerobic $(\mathrm{A}$ and $\mathrm{C})$ or aerobic $(\mathrm{B}$ and D) conditions.

Fig. $6 \mathrm{MNZ}$ degradation (A) and mineralization (B), and anodic coulombic efficiency $\left(C E_{\text {an }}\right)(\mathrm{C})$ as a function of $\mathrm{Fe}(\mathrm{III})$ dosage under the optimum $\mathrm{Mo} / \mathrm{W}$ loading of $0.18 \mathrm{mg} / \mathrm{cm}^{2}$ at a Mo/W ratio of $0.17: 1.0$ and aerobic conditions.

Fig. 7 (A) MNZ degradation in the presence of light irradiation with addition of ammonium oxalate (AO), isopropanol (IP) or benzoquinone (BQ) under anaerobic or aerobic conditions. Comparison of UV-vis absorption spectra of the effluent with or without addition of AO, IP or BQ under anaerobic (B) or aerobic $(\mathrm{C}, \mathrm{D}$ and $\mathrm{E})$ conditions in the presence $(\mathrm{B}, \mathrm{D}$ and $\mathrm{E})$ or absence $(\mathrm{C})$ of illumination light with (E) or without (B, C and D) $\mathrm{Fe}(\mathrm{III})$ addition (anaerobic: Mo/W loading of $0.24 \mathrm{mg} / \mathrm{cm}^{2}$, aerobic: Mo/W loading of $0.18 \mathrm{mg} / \mathrm{cm}^{2}$, a same $\mathrm{Mo} / \mathrm{W}$ ratio of $0.17: 1.0$, operational time: $30 \mathrm{~min}$ ). 
Fig. 8 (-)ESI-MS (A and B) and (+)ESI-MS (C and D) spectra of products of MNZ degradation and mineralization at optimum conditions of Mo/W loading of either $0.24 \mathrm{mg} / \mathrm{cm}^{2}$ (anaerobic, A and C) or $0.18 \mathrm{mg} / \mathrm{cm}^{2}$ (aerobic, Fe(III) addition: 10 $\mathrm{mg} / \mathrm{L}, \mathrm{B}$ and $\mathrm{D}$ ) at a same $\mathrm{Mo} / \mathrm{W}$ ratio of $0.17: 1.0$.

Fig. 9 Proposed MNZ degradation and mineralization pathways in the photo-assisted MFCs with $\mathrm{Mo} / \mathrm{W}$ coated cathodes under anaerobic or aerobic conditions.

Fig. $10 \mathrm{MNZ}$ degradation and mineralization (A and B), and circuital current and anodic coulombic efficiency $\left(C E_{\mathrm{an}}\right)(\mathrm{C}$ and $\mathrm{D})$ as a function of number of batch cycles with fresh MNZ catholyte under anaerobic (A and C) or aerobic (B and D) conditions with Mo/W loading of either $0.24 \mathrm{mg} / \mathrm{cm}^{2}$ (A and C) or $0.18 \mathrm{mg} / \mathrm{cm}^{2}$ (B and D) (Mo/W ratio of $0.17: 1.0$; operation time per cycle: $60 \mathrm{~min}$; added $\mathrm{Fe}(\mathrm{III})$ under aerobic conditions: $10 \mathrm{mg} / \mathrm{L}$ ).

Fig. 11 A schematic mechanism of MNZ degradation and mineralization in the combining photo-assisted MFCs and Fenton-MFCs with Mo/W coated cathodes under anaerobic or aerobic conditions. 
Click here to download high resolution image
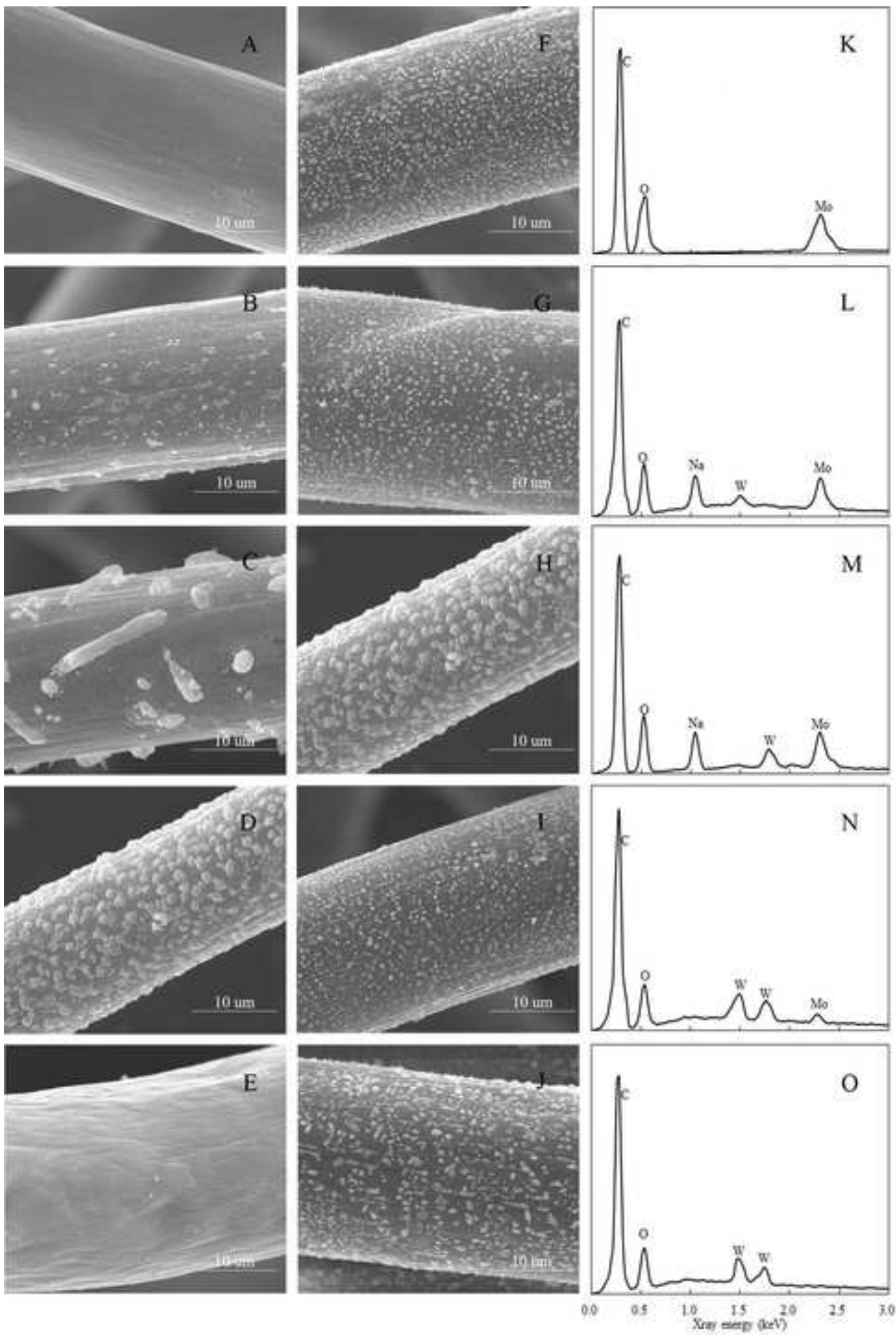


\section{Figure 2}

Click here to download high resolution image
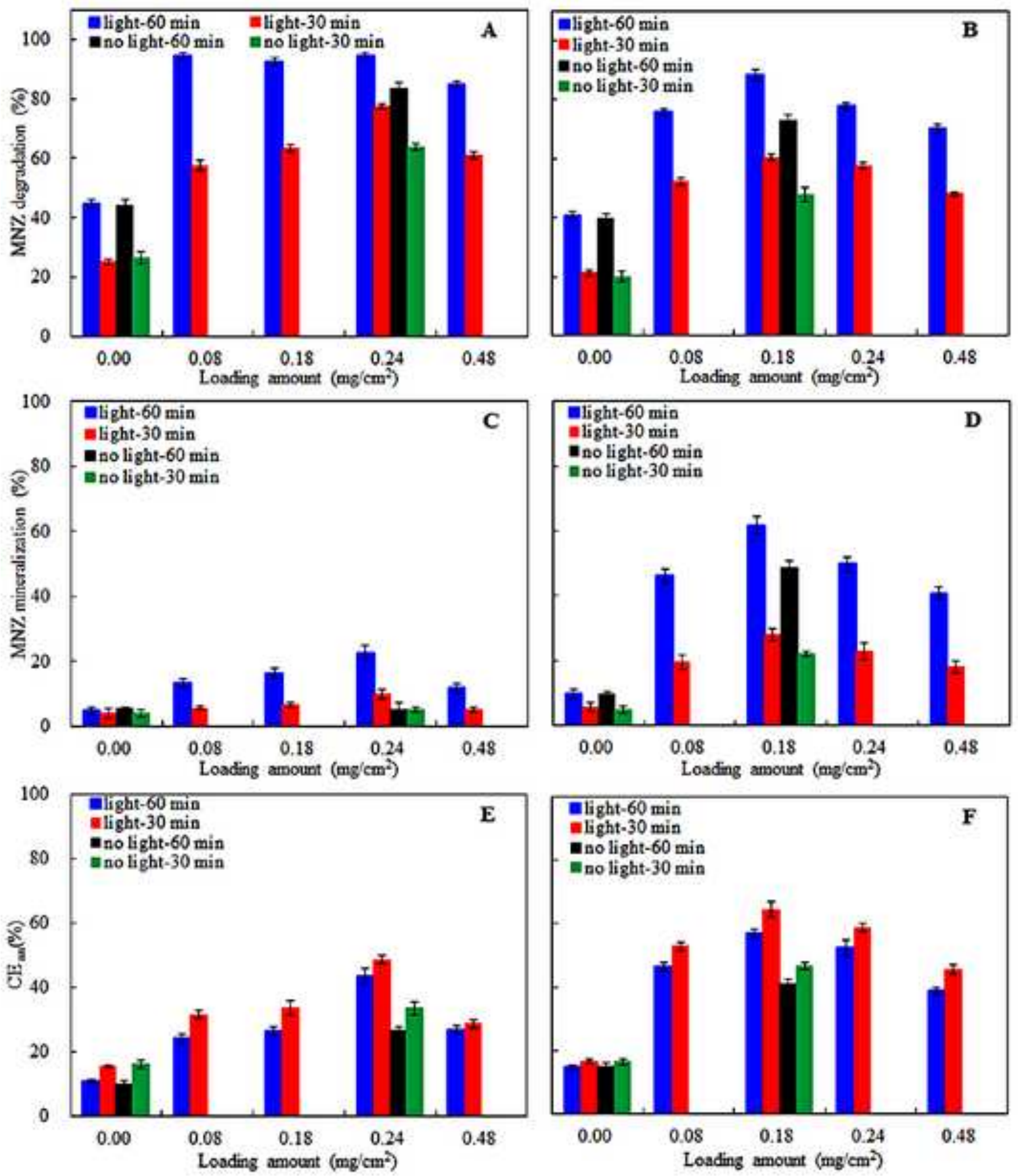
Click here to download high resolution image
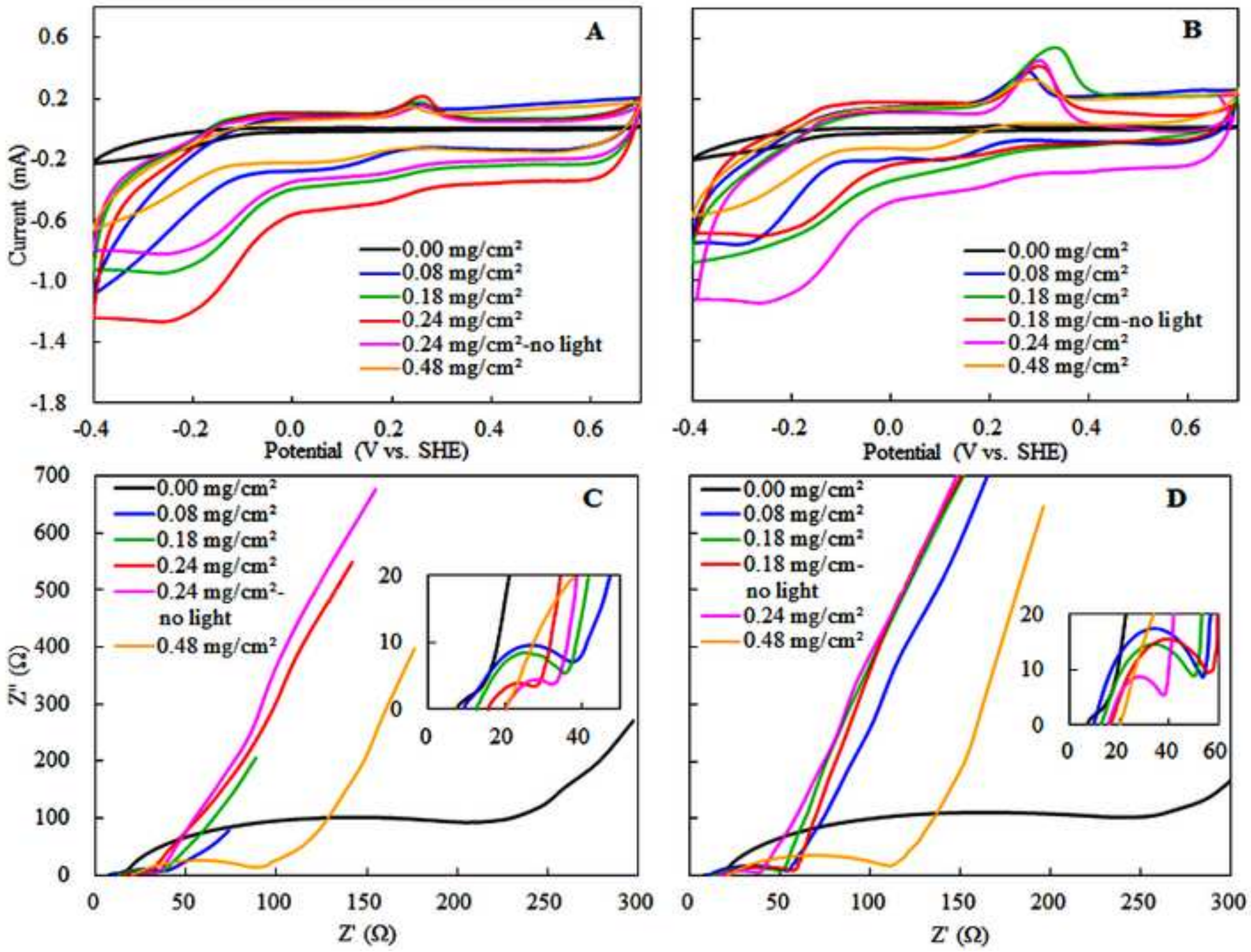

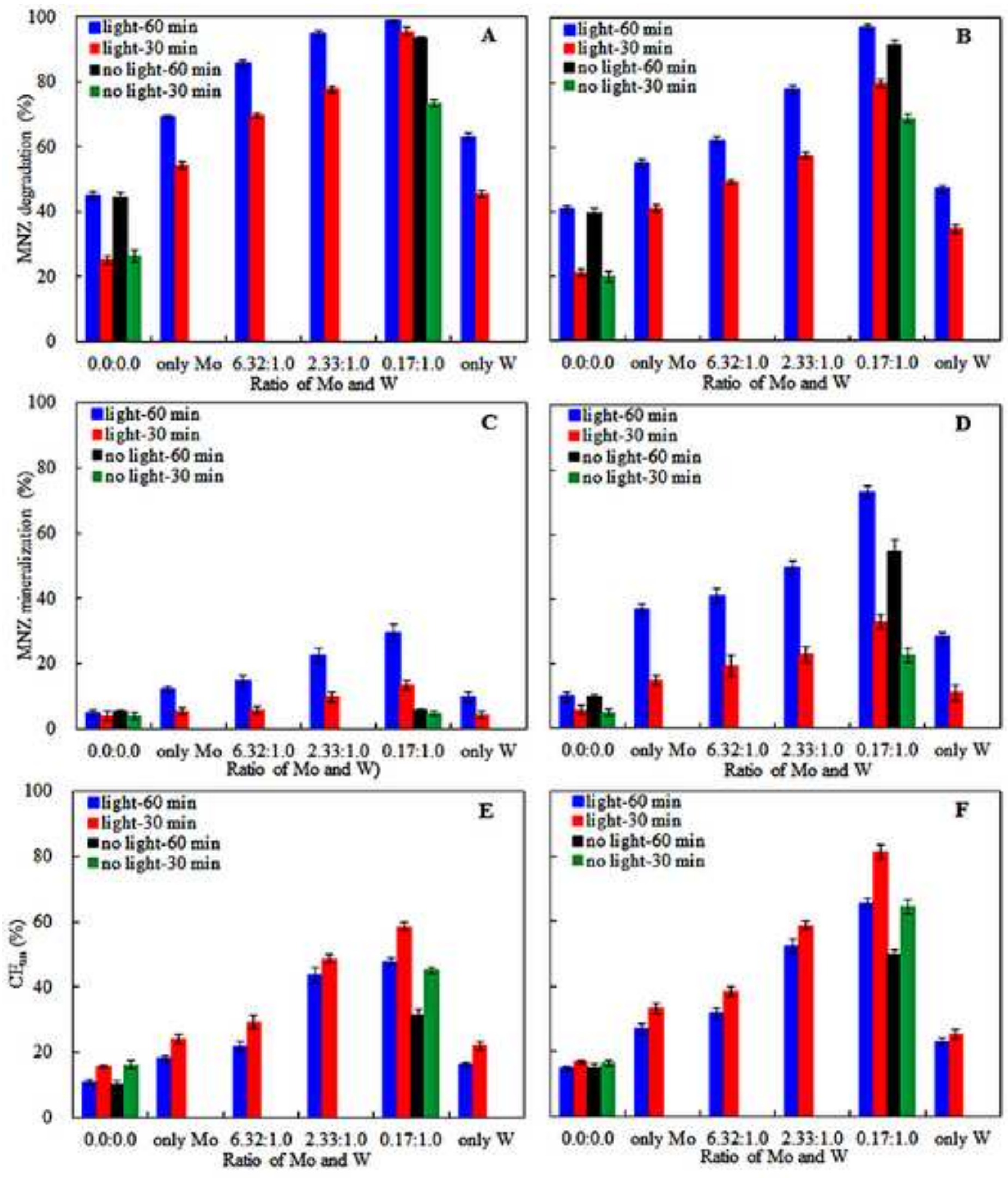

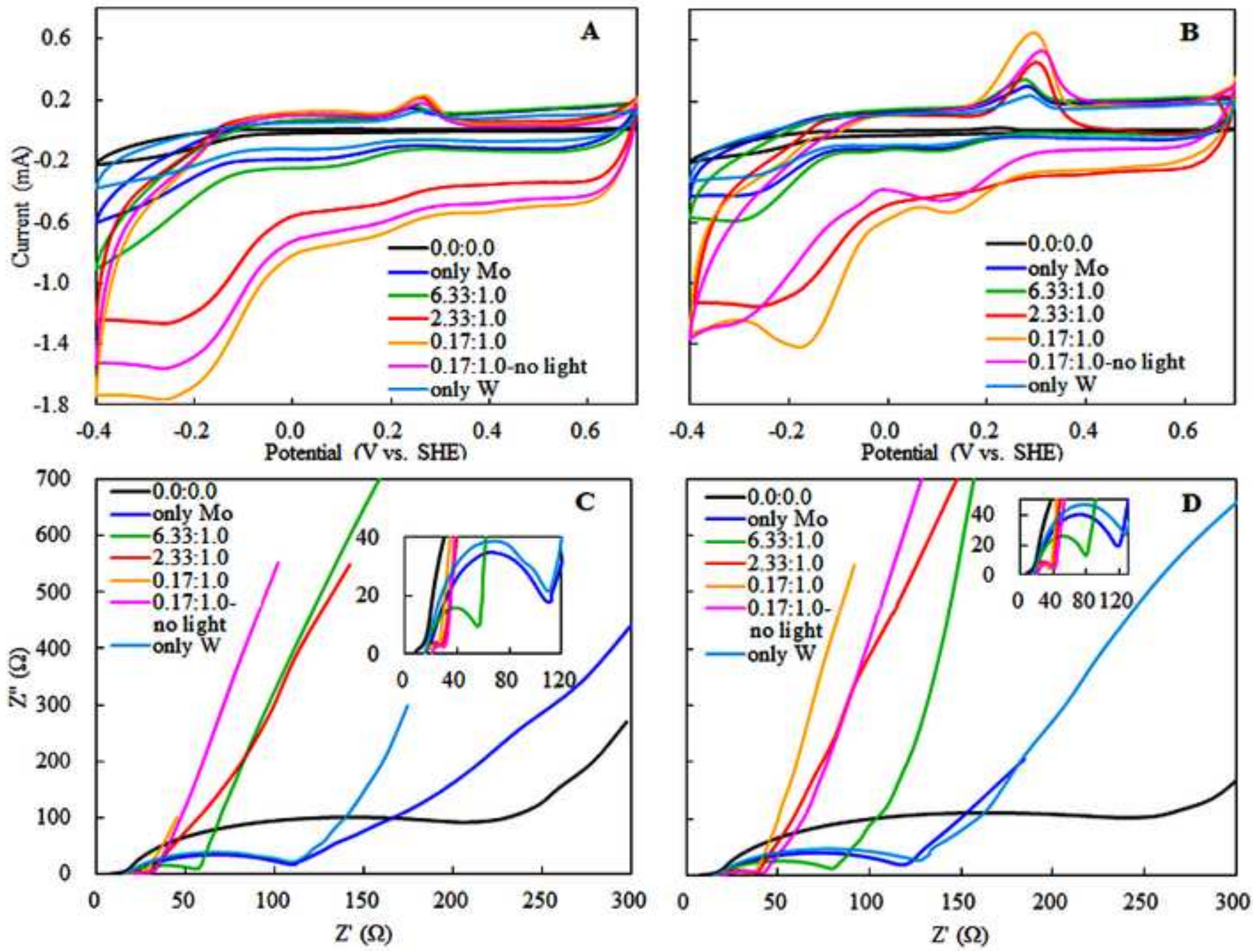
Figure 6

Click here to download high resolution image
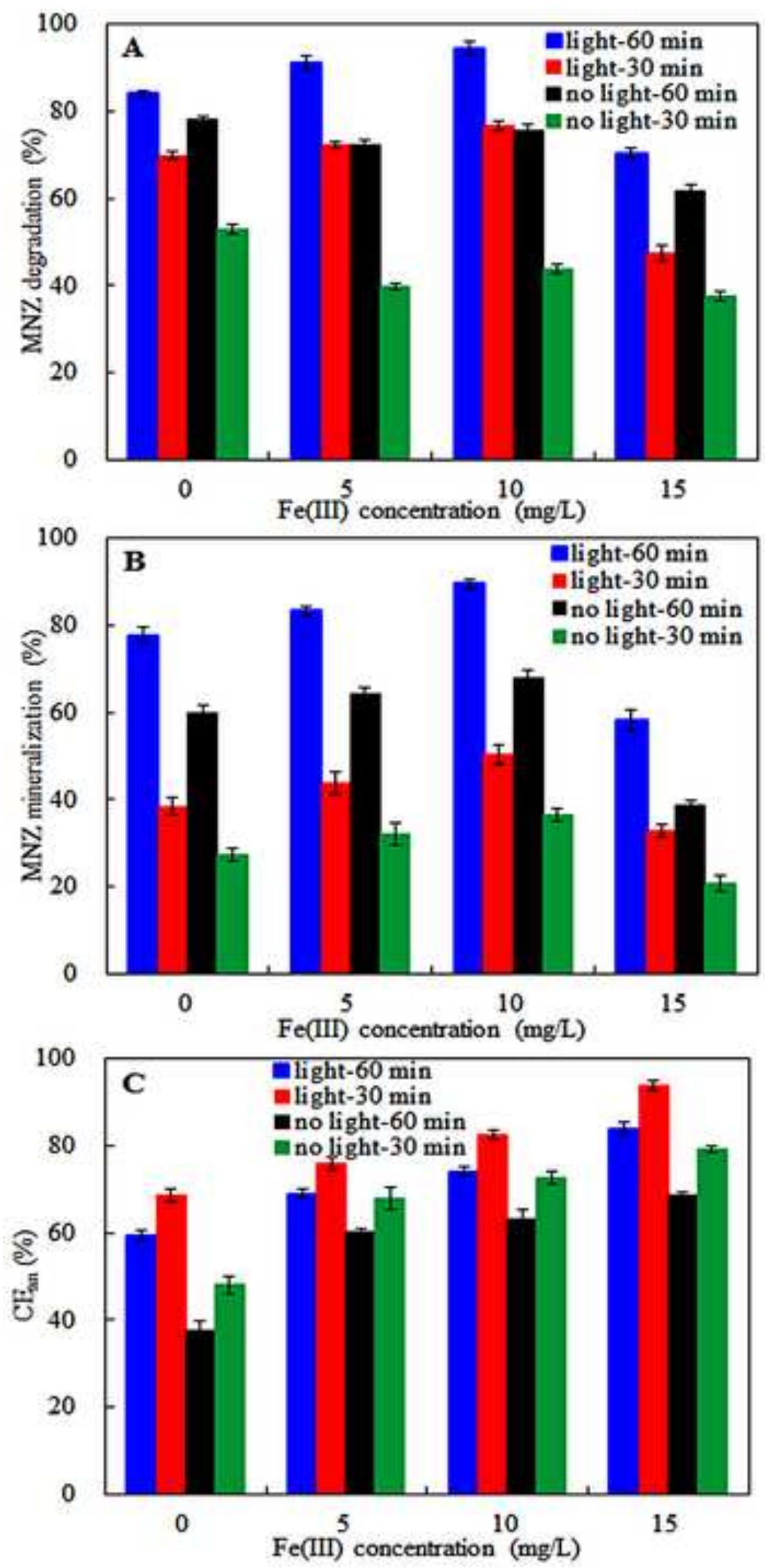


\section{Figure 7}

Click here to download high resolution image

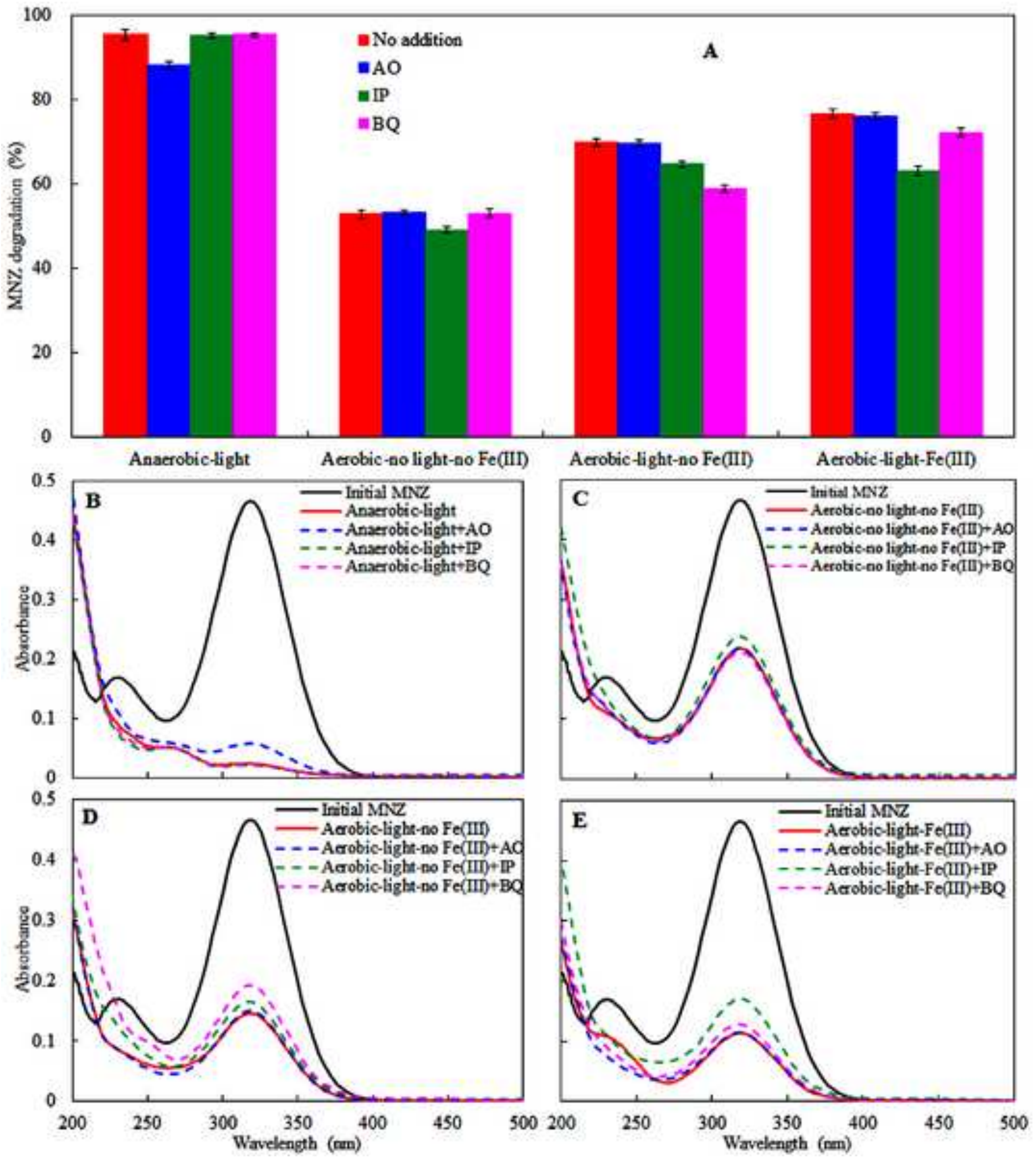



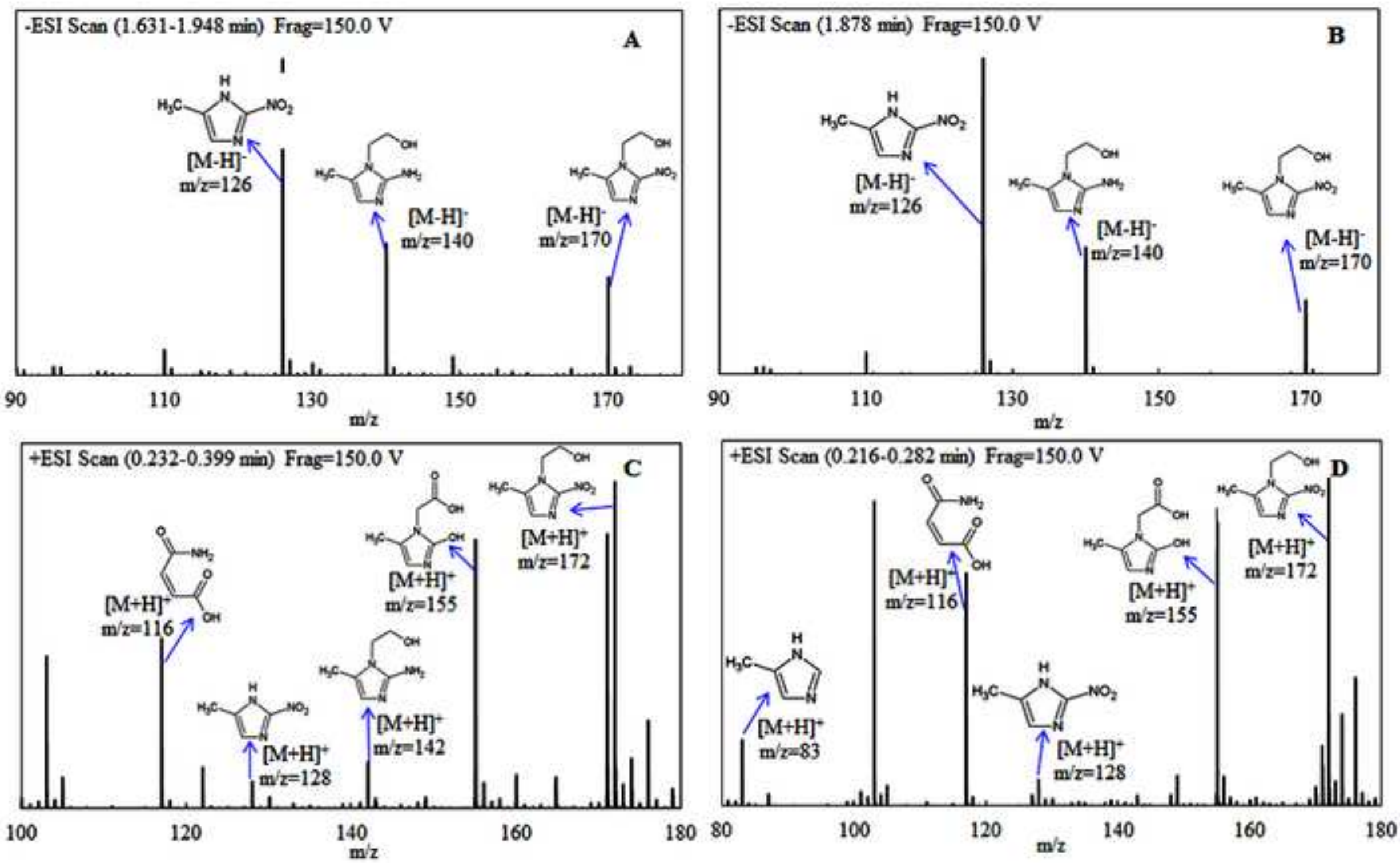


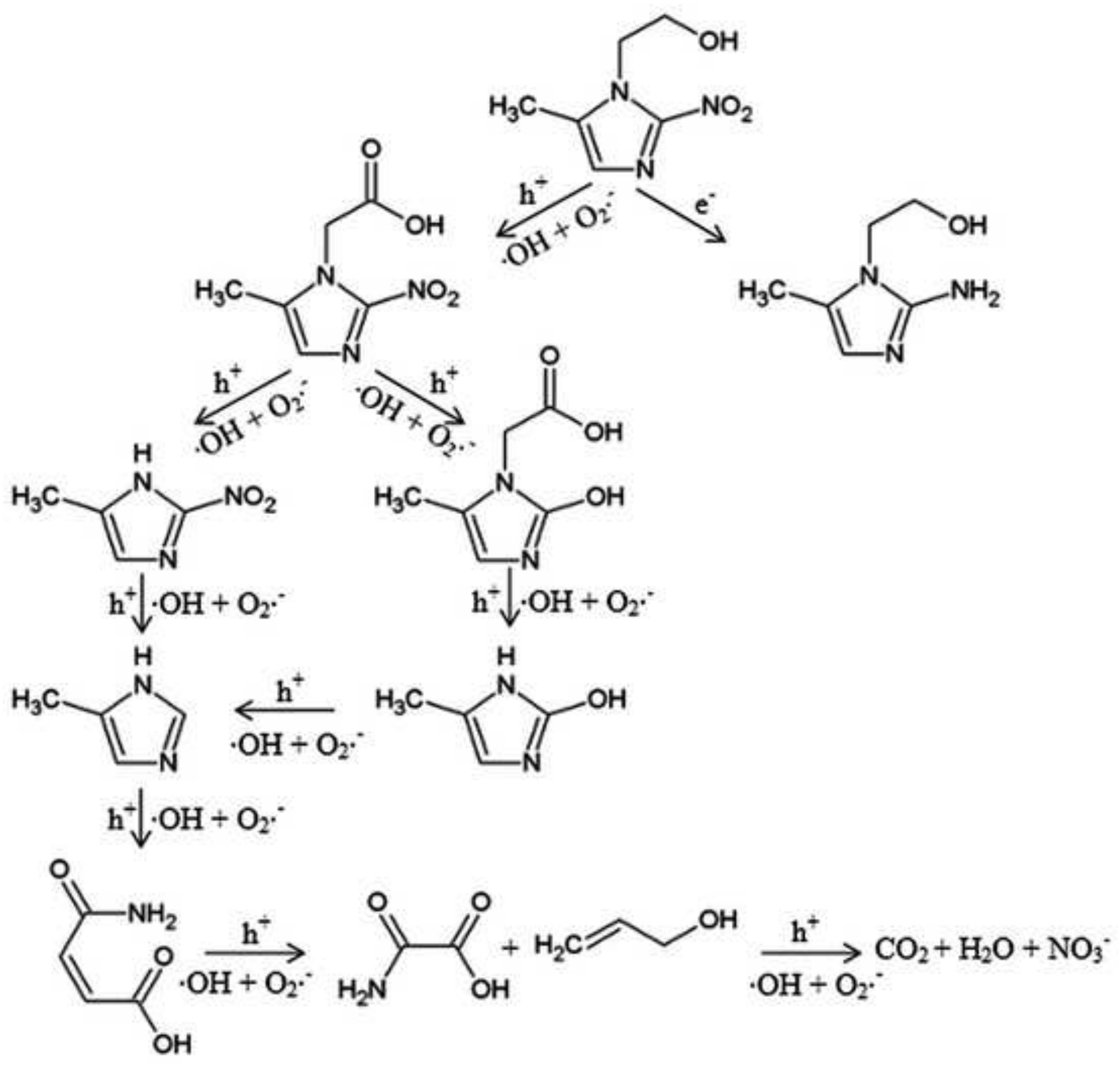


Click here to download high resolution image
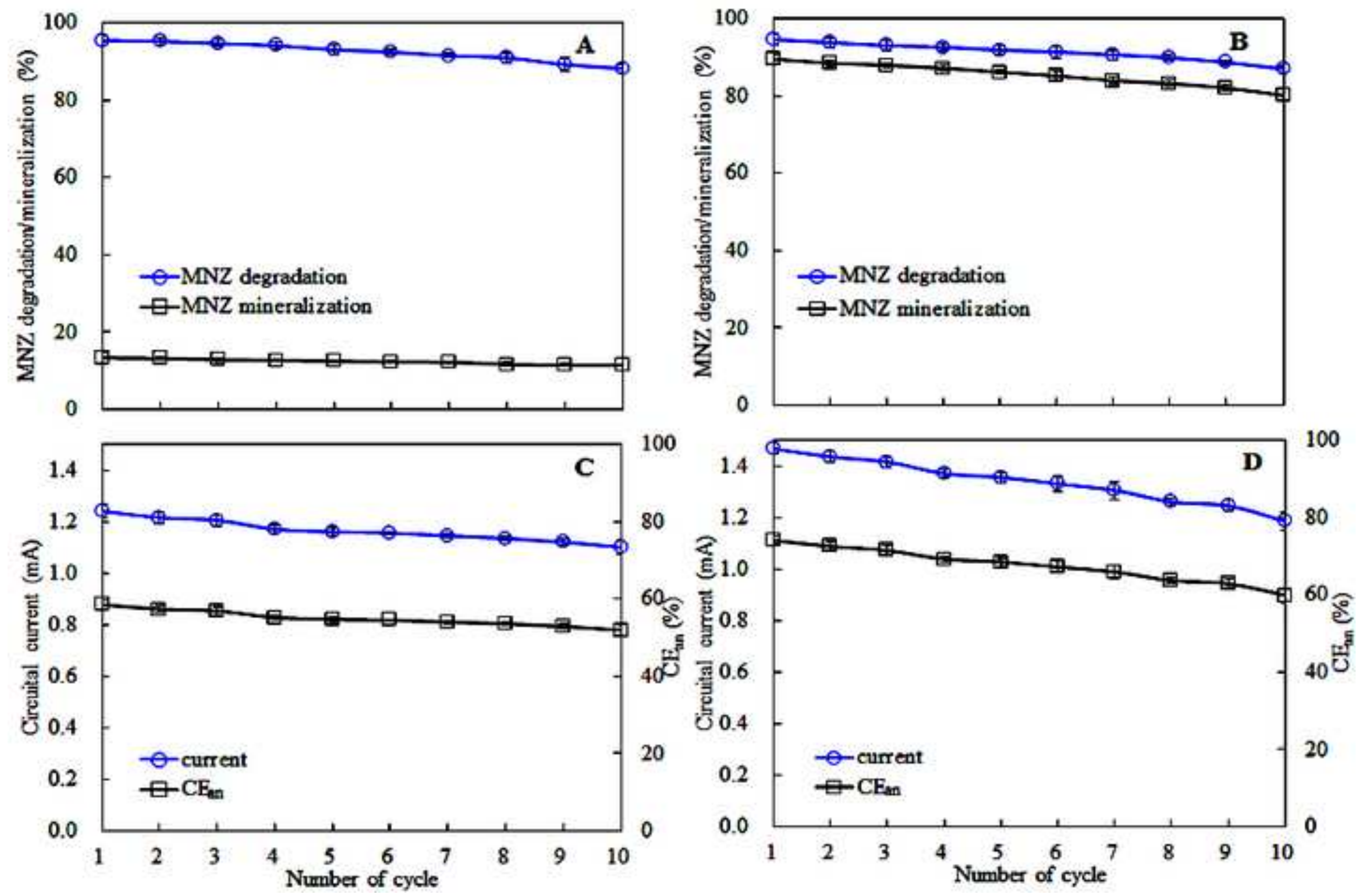


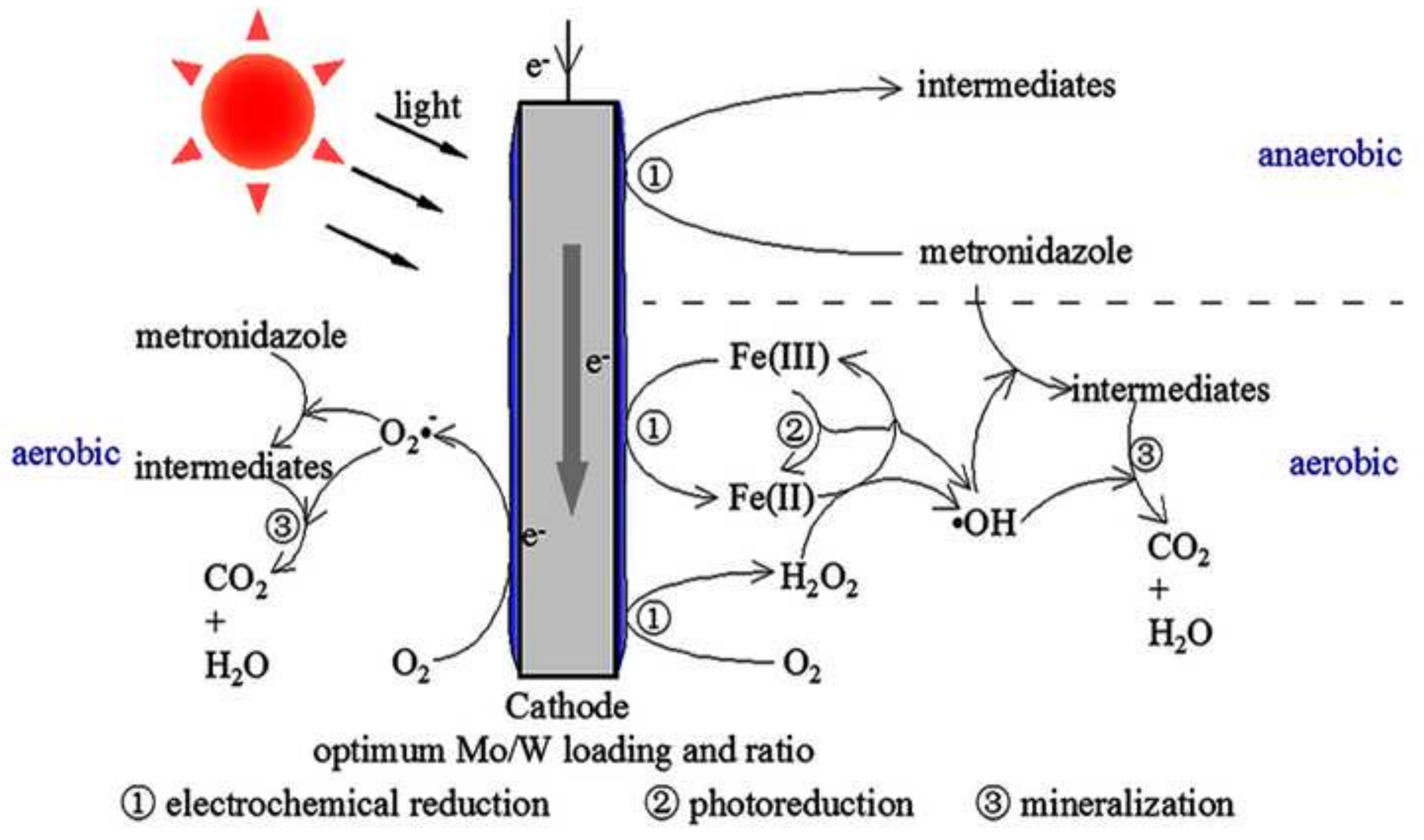


Supplementary Material
Click here to download Supplementary Material: Supporting Information.doc

Supplementary Material
Click here to download Supplementary Material: Supporting Information.doc

(a)

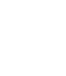

$\sqrt{3}$

(1) (1)

(1)

(1) (1)

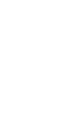

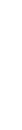

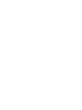

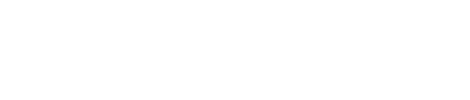

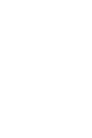

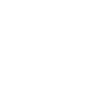
. . (n)

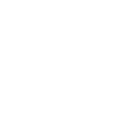

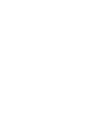
$x^{2}$ .

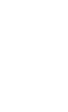
$x^{2}$

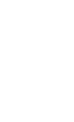

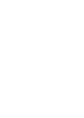

